\title{
PLANO DE EMPREENDIMENTO: LOJA DE ROUPAS E ARTIGOS INFANTIS
}

Recebido em 02.04.2017. Aprovado em 30.04.2017

Avaliado pelo sistema double blind review

Fabiana da Conceição Mendes

fabiana_mendes@id.uff.br

Departamento de Empreendedorismo e Gestão - Universidade Federal Fluminense - Niterói -RJ

\section{Sumário Executivo}

Através da observação direta do empreendedor no mercado de Itaipuaçu, município de Maricá/RJ, foi identificada uma demanda por um estabelecimento que oferte produtos infantis. Dessa forma, realizou-se este plano para abertura de uma loja de roupas e artigos infantis. A empresa busca atender ao público local, no que tange a produtos infantis, classe média, com faixa etária de usuários de 0 a 14 anos. Visa ofertar produtos de qualidade, excelência no atendimento e bom preço. Os principais objetivos são: Atender as necessidades dos clientes com roupas e acessórios, calçados, brinquedos, higiene pessoal e cosméticos, utilidades, passeios e enxoval; E ser líder do ramo no comércio local, sendo reconhecida como uma loja atrativa que supre as expectativas dos clientes. Em termos de faturamento, nos 3 anos iniciais de sua existência, a empresa espera pagar seus custos e despesas, recuperar o investimento inicial e começar a ter lucro. Para concretizar o Plano de Negócios, com vistas à locação do imóvel, adequação, legalização e aquisições tanto para composição da loja, quanto de suprimentos para comercializar, presume-se a necessidade de um investimento aproximado de $\mathrm{R} \$ 100.000,00$ (cem mil reais).

Palavras-chaves: Plano de Empreendimento; Roupas infantis; Empreendedorismo. 


\section{Caracterização da empresa}

\section{Apresentação da empresa e do seu foco de atuação}

O empreendimento aqui apresentado é uma loja varejista de roupas e artigos infantis, a ser inaugurada no bairro de Itaipuaçu, no município de Maricá/RJ. O negócio foi pensado inicialmente para o público de classe média, com faixa etária de usuários de 0 a 14 anos.

A loja conta com um espaço aproximado de $70 \mathrm{~m} 2$, onde objetiva-se exposição/venda de vasta gama de produtos, com vistas à qualidade e bom preço, proporcionando ao público de Itaipuaçu a oportunidade de consumir produtos para suas crianças sem que precise se deslocar do bairro onde moram. Busca-se atender necessidades dos clientes no que tange o público infantil, com roupas, calçados, enxoval, passeio e utilidades, acessórios e brinquedos, higiene pessoal e cosméticos.

O que proporcionou a oportunidade de negócio para a abertura da loja, cuja marca será "Kids Açu", foi a observação direta por parte do empreendedor, de que Itaipuaçu tem muitas crianças e pouca oferta de produtos para as mesmas.

A loja visa ainda sua implantação em local estratégico, situando-se ao lado de uma clínica com atendimento pediátrico e pelo menos 03 escolas particulares em seus arredores, bem como 03 cursos de línguas (CNA, FISK e YES).

\section{Perfil do empreendedor}

O empreendedor com interesse no negócio foi morador do bairro e atua no comércio local há mais de 20 anos, no ramo imobiliário. Através de observação da representatividade de público, e a baixa demanda de oferta local, considerou interessante investir no ramo infantil, pensando então na abertura da loja.

\section{Descrição Legal}

Este empreendimento demanda espaço adequado e boa localização, e para sua legalização faz-se necessário o que segue:

- Aprovação de alvará;

- Laudo de bombeiro (extintor de incêndio);

- Registro de CNPJ;

- Registro na Junta Comercial;

- Inscrição Estadual;

- Aprovação da vigilância sanitária;

- Enquadramento contábil (o empreendedor pensa em abrir o negócio sozinho, na modalidade Eireli, optante pelo Simples Nacional);

- Aprovação de nome (pensa-se inicialmente no nome "KIDS AÇU", mas também serão apresentados "BABYAÇU" e AÇU KIDS);

- Certificação digital;

- Aprovação da prefeitura para colocar letreiro. Organização e governança 0 projeto vislumbra a contratação de um gerente, já que o empreendedor não tem tempo para ficar à frente do negócio, e uma vendedora, que deverá ter experiência com vitrines e vendas. Caberá a cada funcionário:

- Empreendedor: Contratação de funcionários; análises de faturamentos e despesas/custos; aprovação para realização de compras de mercadorias; precificação de produtos, contando com auxilio do gerente; estratégias de divulgação; acompanhar perfis nas redes sociais; fazer pagamento de salários e possíveis comissões aos funcionários. 
- Gerente: Abre a loja pela manhã; dirige e desenvolve os vendedores; fica atento ao atendimento que está sendo realizado; auxilia atendimentos prezando pela excelência; preza pela limpeza e organização da loja; faz e auxilia na composição da vitrine; checa estoque; realiza controle de entradas e saídas de mercadorias; faz contato com fornecedores; coordena periodicamente a realização de inventários e balanços; auxilia empreendedor a precificar mercadorias; responsável pela parte financeira deve atuar no caixa e precisa fazer seu fechamento diariamente, controlar pagamentos a fornecedores; atentar aos meios de divulgação do negócio; promoção de relacionamento com clientes nas redes sociais; mantém constante comunicação com 0 empreendedor; fecha loja.

- Vendedora: Realiza limpeza da loja; organiza produtos expostos; auxilia clientes em suas compras, demonstrando produtos e seus benefícios, e propaga as promoções existentes; monta vitrine; passa roupas quando necessário; deve ser simpática, solícita, estar sempre com vestimenta limpa, cabelo arrumado, ser comunicativa, ter entrosamento e gostar de crianças.

OBS.: Havendo demanda, em períodos sazonais, poderão ser feitas contratações de funcionários temporários.

Organograma de funções:

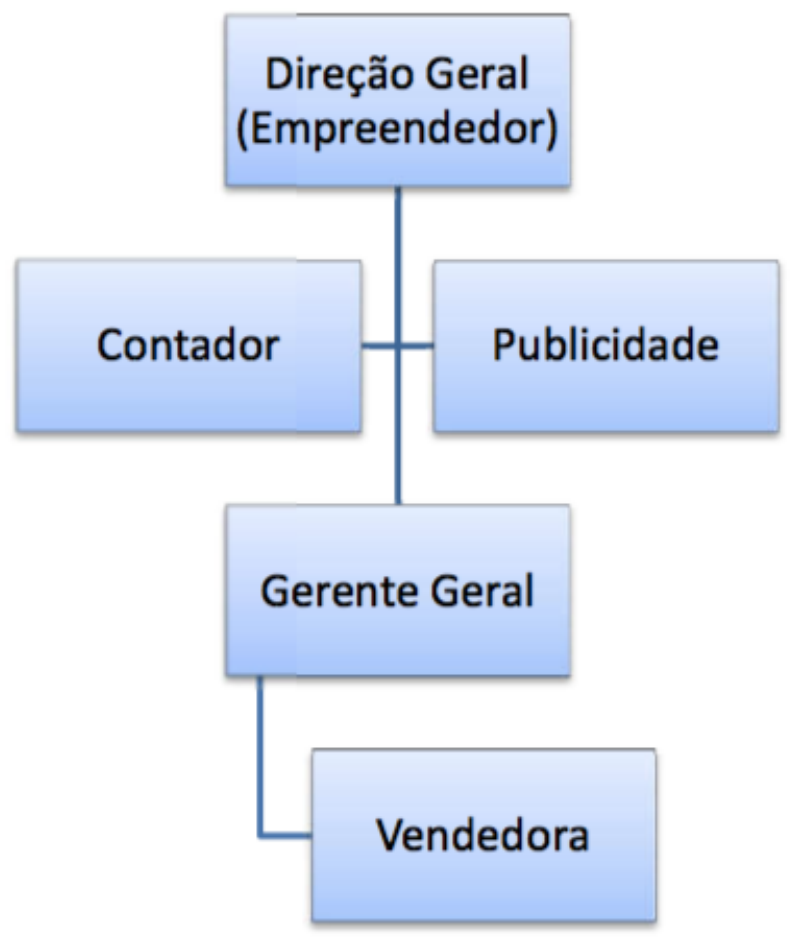


Principais processos de trabalho

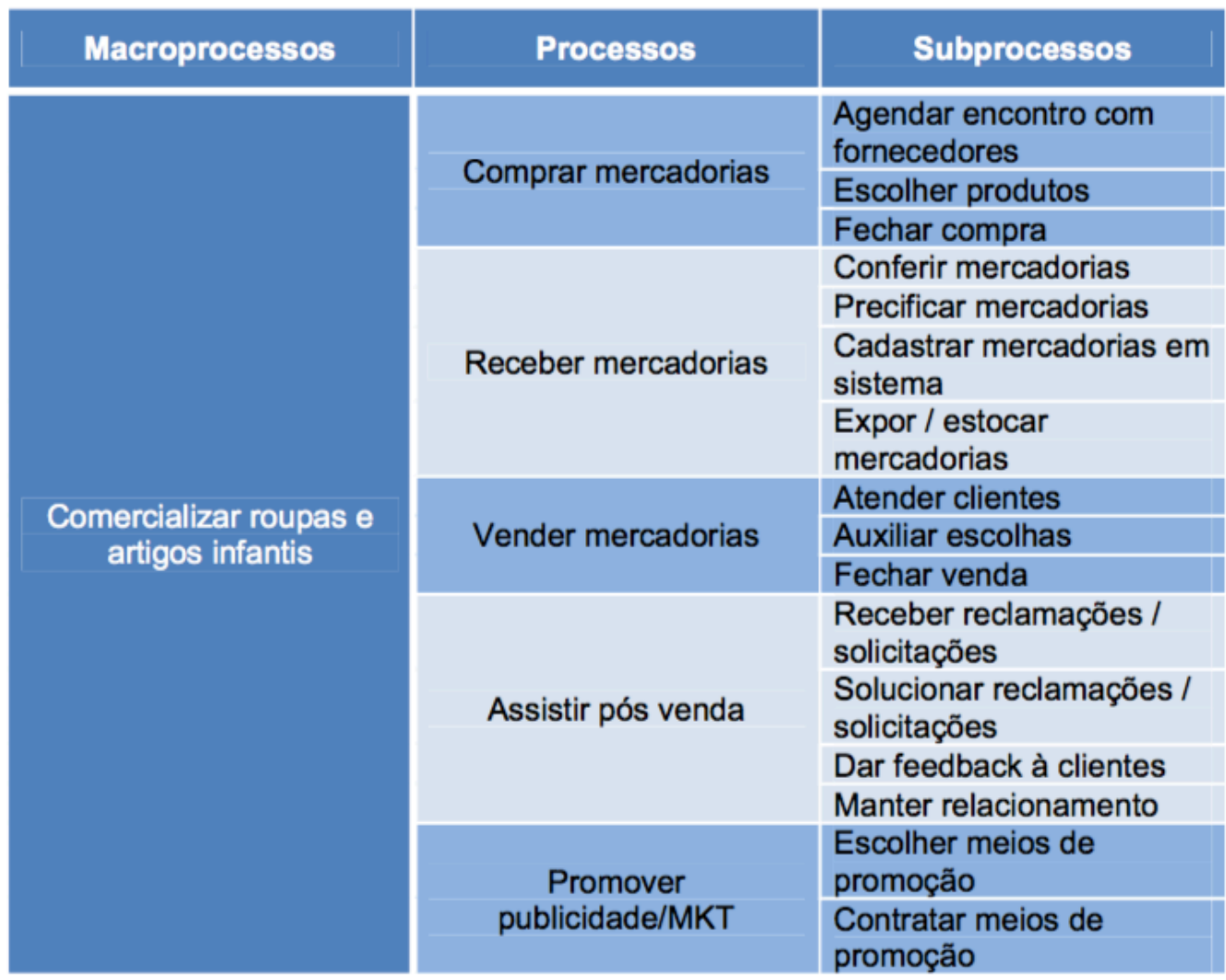

Obs.: Nos anexos há o detalhamento dos principais processos de trabalho.

\section{Descrição da estrutura física e layout}

O espaço considerado para abertura da loja possui aproximadamente $70 \mathrm{~m} 2$, onde projeta-se:

- Cozinha para funcionários;

- Escritório para atuações burocráticas;

- Banheiros (masculino e feminino);

- Espaço para amamentação e troca de fraudas;

- Balcão de Caixa;

- Provador c/ espelho;

- Frente com vidro temperado e vitrine atrativa ao público que vê de fora (disposição de manequins compondo looks);

- Armários com gavetões inferiores e expositores na parte superior, nas laterais da loja;

- Aramados dispostos no centro da loja, formando corredores de passagens;

- Espaço para exposição de produtos promocionais;

- Espaço Kids (atrações para as crianças se divertirem);

- Paredes coloridas;

- Disposição dos mostruários de vestuários separados por faixa etária e sexo;

- Disposição de demais produtos também por faixa etária;

- Lixeira infantil com proposta seletiva; 
- Frente da loja com vasos de plantas;

- Fachada em vermelho com logo da loja (colorido);

- Lateral na frente da loja com painel para propagandas;

- Rampa de acesso para cadeirantes e carrinho de bebê;

- Piso da calçada antiderrapante.

Esquema representativo das instalações sem mercadorias:

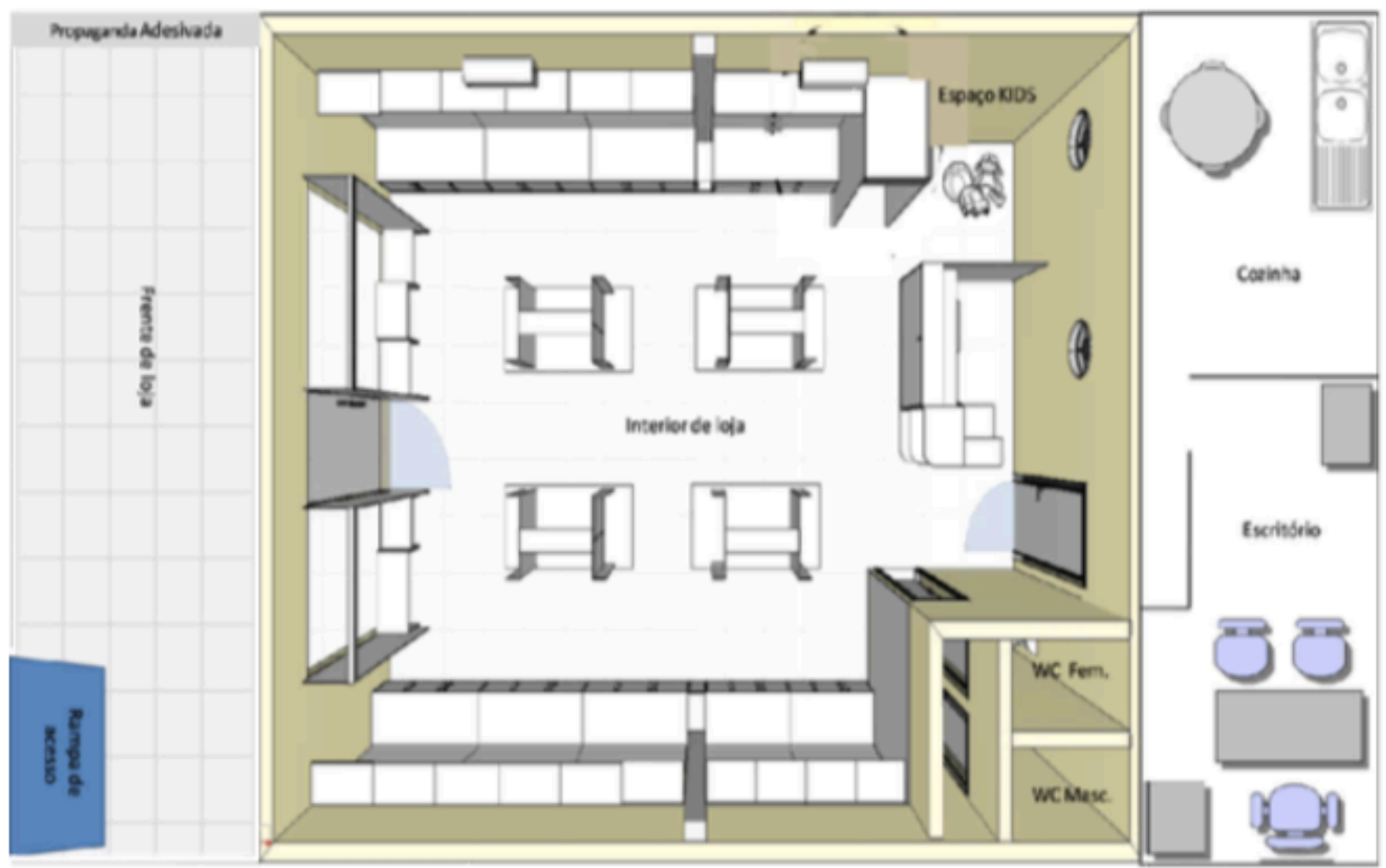

Logo pensada para a loja:

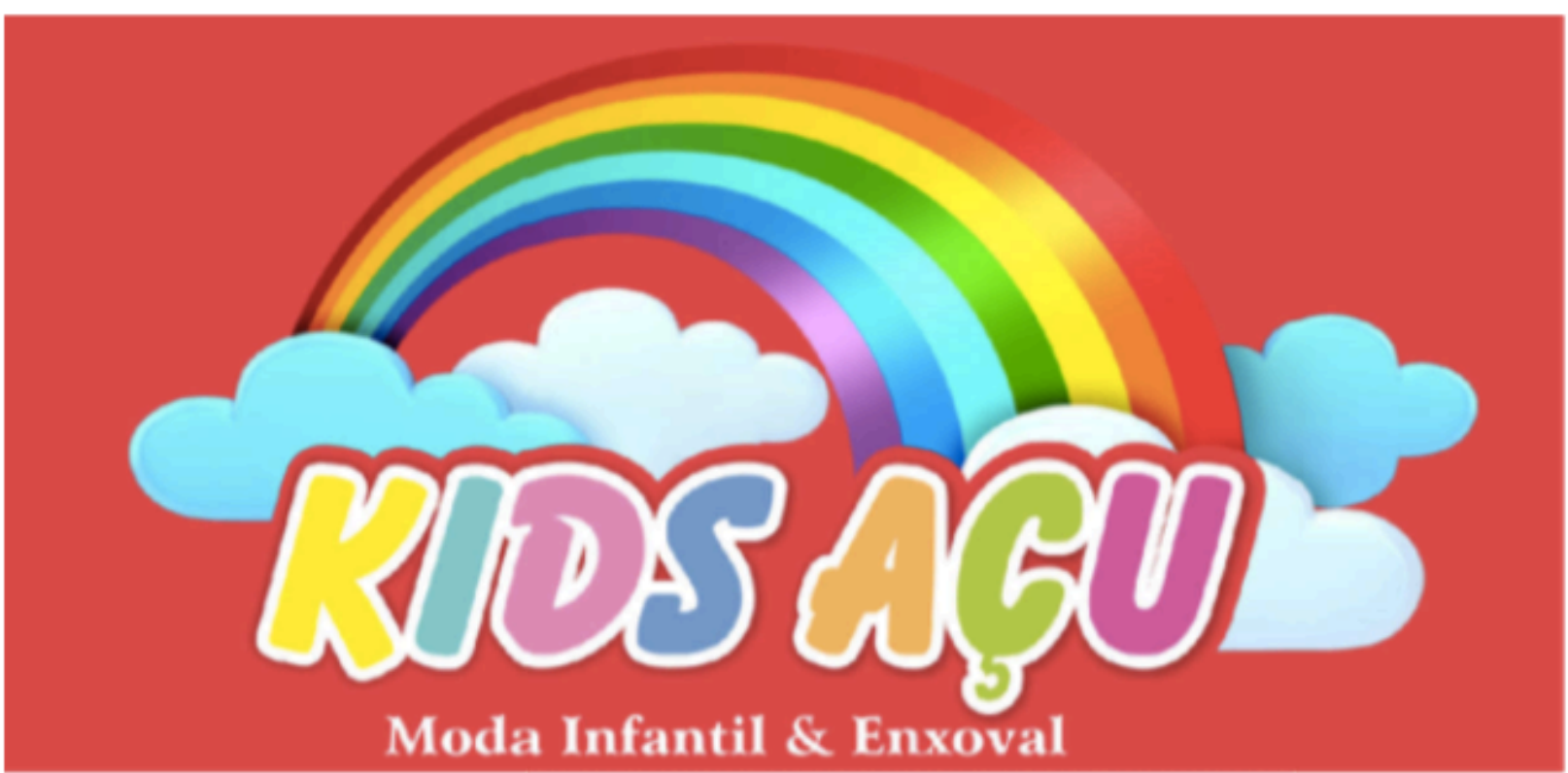




\section{ANÁLISE DE MERCADO}

\section{Panorama e dimensionamento do mercado}

\section{Nível Brasil}

São apresentados a seguir elementos que contribuem para a caracterização do mercado em âmbito nacional:

- A fase infantil da vida do ser humano é de desenvolvimento constante, demandando trocas de roupas e compra de produtos inerentes a cada fase na mesma proporção, como aponta o estudo "Segmento de vestuário infantil é mercado crescente no país", realizado pelo SEBRAE1.

- Em 28/05/2015, a Abras Brasil ${ }^{2}$ realizou estudo mostrando que o mercado de moda infantil resiste à crise e sustenta venda das redes. Mostra que nem o consumo enxuto mudou os planos de expansão de marcas do ramo. A força do apelo emocional quando o assunto é vestuário e acessórios infantis costuma dar segurança às marcas.

- A marca Marisol, com expertise no segmento de confecção para o público infantil, resolveu em 2015, investir em sistema de franquias para abertura de lojas nas principais cidades brasileiras. A previsão é chegar a 200 lojas nos anos seguintes. Até então, a marca vendia para 10 mil lojas multimarcas. Segundo o gerente de novos negócios da marca Marisol, eles demoraram um ano para formatar 0 conceito e a estratégia do negócio, tendo em vista que o público infantil hoje tem voz ativa na decisão dos produtos a serem adquiridos e, por isso, o conceito da nova empreitada da empresa, foi amplamente estudado, desde o mobiliário até a disposição dos produtos.

- O estudo da Abras Brasil (2015), ainda aponta que investir no setor parece algo atrativo, afinal 0 mercado de artigos infantis em geral movimenta cerca de $\mathrm{R} \$ 50$ bilhões por ano. Normalmente, 0 segmento apresenta crescimento médio anual de $14 \%$. Assim tudo indica que em períodos de crise, ou não, as empresas que atuam nesse ramo mantêm planos de expansão.

- Em geral, as famílias de classe média desembolsam cerca de $\mathrm{R} \$ 5$ mil no primeiro ano de vida dos pequenos. De olho nisso, a rede Alô Bebê também segue com apetite atrás dos clientes que vão das gestantes às crianças de 12 anos, de ambos os sexos.

- A rede Alô Bebê apresentou em 2015 um crescimento, em torno de 5\%, observado já no primeiro quadrimestre das vendas no ano. A rede contava em 2015 com 24 unidades, objetivando chegar a 30. Entre os meses de maio e junho, inaugurou três lojas, sendo duas em São Paulo e uma no Rio de Janeiro, visando à implantação de mais lojas na região Sudeste e Centro-Oeste. Estudos apontaram que a bandeira atrai um público familiar completo e que os clientes têm hábitos de ir à rede com frequência de 15 em 15 dias. Na Alô Bebê, o departamento de puericultura representa $40 \%$ das vendas. Os itens mais procurados são carrinhos de bebê, cadeirão, cadeiras de

1 http://www.sebrae.com.br/sites/PortalSebrae/artigos/segmento-de-vestuario-infantil-e-mercado-crescente-nopais,3c864dee85367410VgnVCM1000003b74010aRCRD

$2 \quad 2$ http://www.abrasnet.com.br/clipping.php?area=19\&clipping $=50927$ 
automóveis. A parte do vestuário representa por volta de $20 \%$ do marketshare e o restante é pulverizado entre brinquedos, calçados, cama e banho.

\section{Nível local (Itaipuaçu - Maricá/RJ)}

Com base nos estudos apontados, observamos a atratividade do setor. Identificando por meio de observação direta, que o bairro Itaipuaçu, localizado no município de Maricá/RJ, apresenta pouca oferta de mercado no ramo, surgiu a oportunidade de empreender no mesmo.

Itaipuaçu conta com uma população estimada de 30 mil habitantes, segundo o jornal do município Lei Seca Maricá3. São quatro as lojas encontradas no comércio local voltadas ao público infantil, onde observa-se a pouca variedade de produtos ofertados e a localização afastada do grande centro comercial do bairro.

Observa-se também, a existência de várias escolas infantis particulares nas proximidades de onde se pretende implantar a loja, bem como há ao lado, uma clínica médica com atendimento pediátrico. $O$ público de interesse são as famílias locais pertencentes às classes $C$ e $D$, podendo eventualmente atender a classe B. Para validação e aprofundamento das percepções iniciais sobre o público-alvo foi realizada uma pesquisa de mercado na região. Foram obtidas 34 respostas, que apontaram para seguintes resultados:

\section{É morador de Itaipuaçu?}

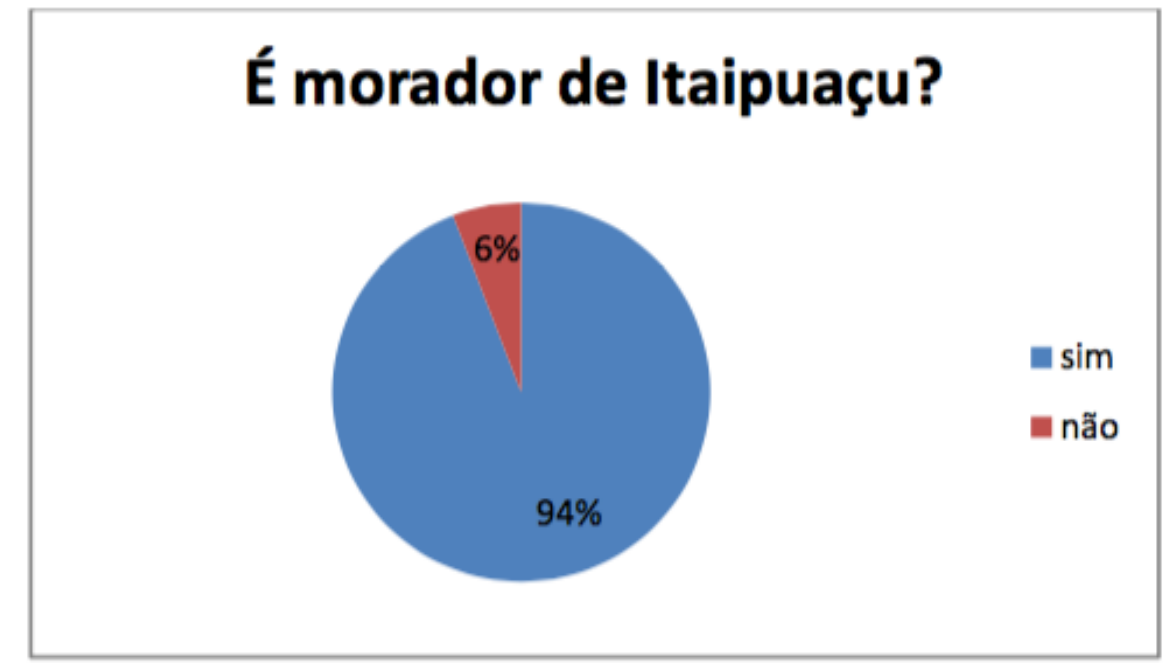

Esta pergunta foi realizada com o intuito de verificar se o respondente é um possível consumidor local.

\footnotetext{
${ }^{3}$ http://leisecamarica.com.br/marica-200-anos-conheca-um-pouco-da-historia-do-bairro-de-itaipuacu/
} 


\section{Trabalha em Itaipuaçu?}

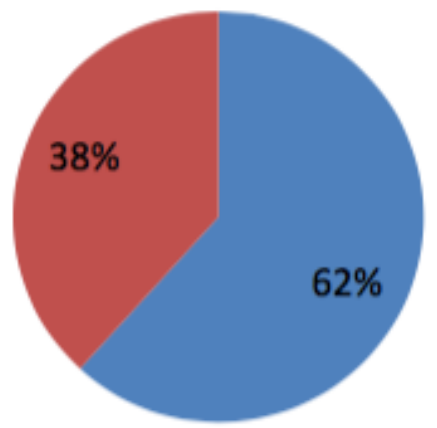

Esta pergunta foi realizada com o intuito de verificar se o respondente é um possível consumidor local.

\section{Tem filhos com até 14 anos?}

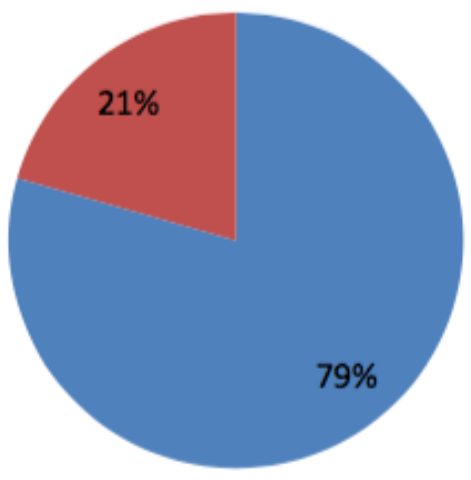

- Sim

não

Esta foi uma pergunta realizada a fim de identificar demanda por produtos infantis. 


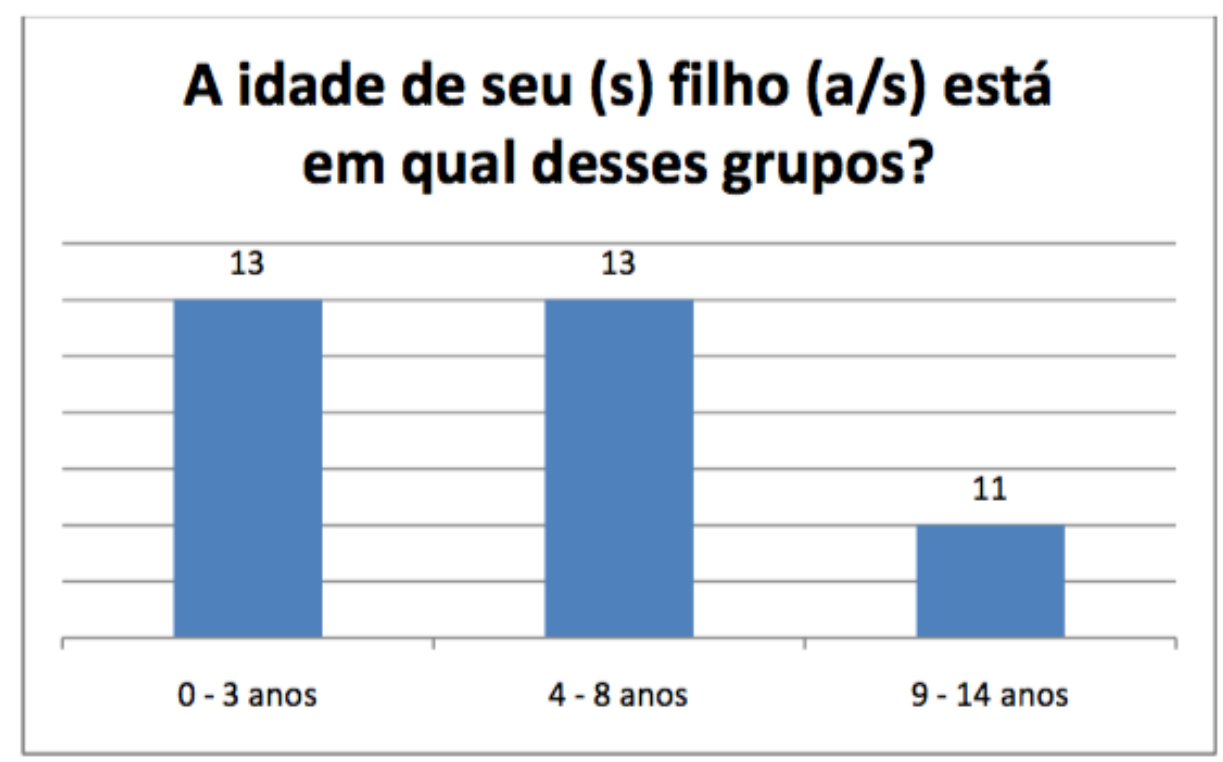

Esta pergunta visa identificar grupos de idade que se pode priorizar ao adquirir produtos para a loja.

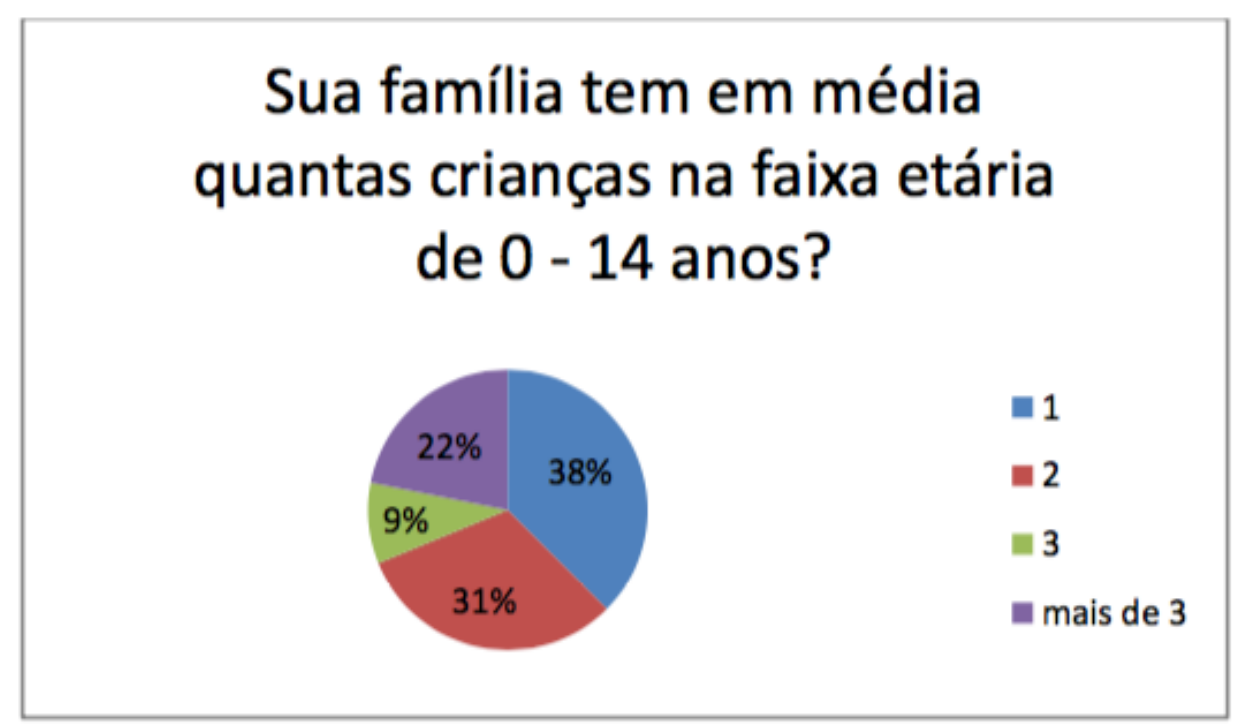

Aqui buscou-se identificar demanda por produtos infantis. 


\section{Consome produtos para crianças no comércio de Itaipuaçu?}

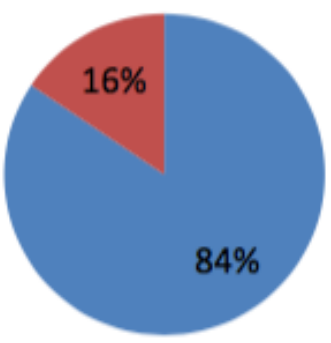

Esta questão visou identificar potenciais clientes para loja.

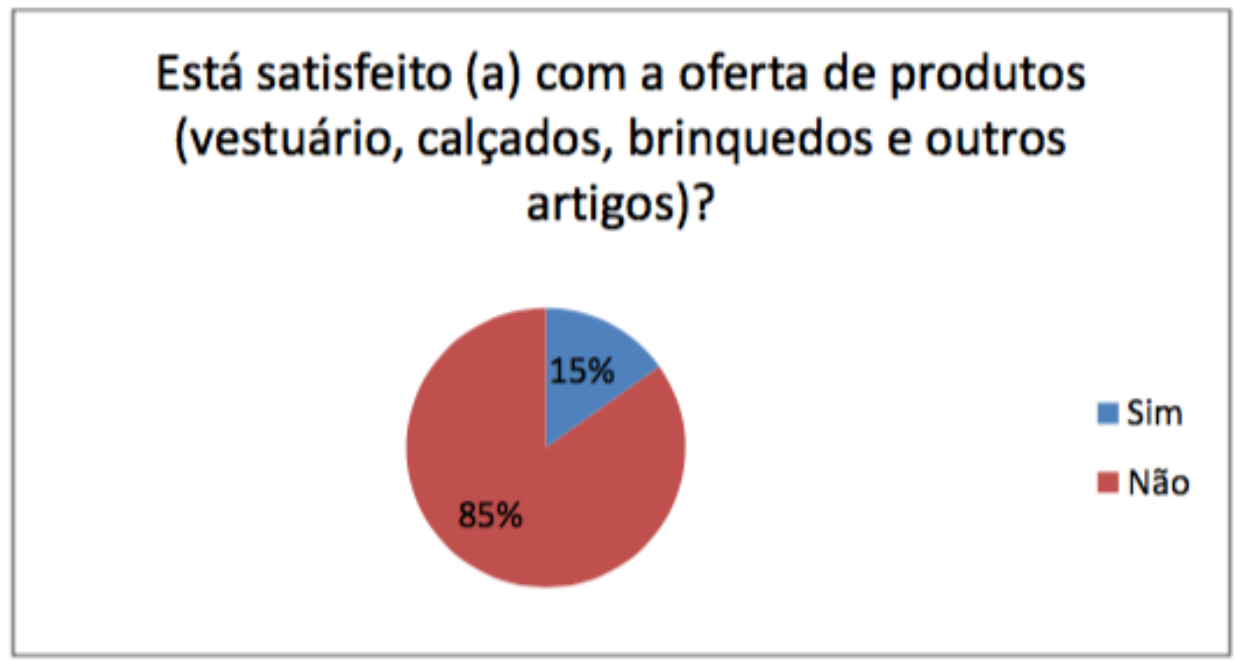

Aqui o intuito foi identificar o grau de satisfação dos clientes para buscar oportunidades de diferenciação.

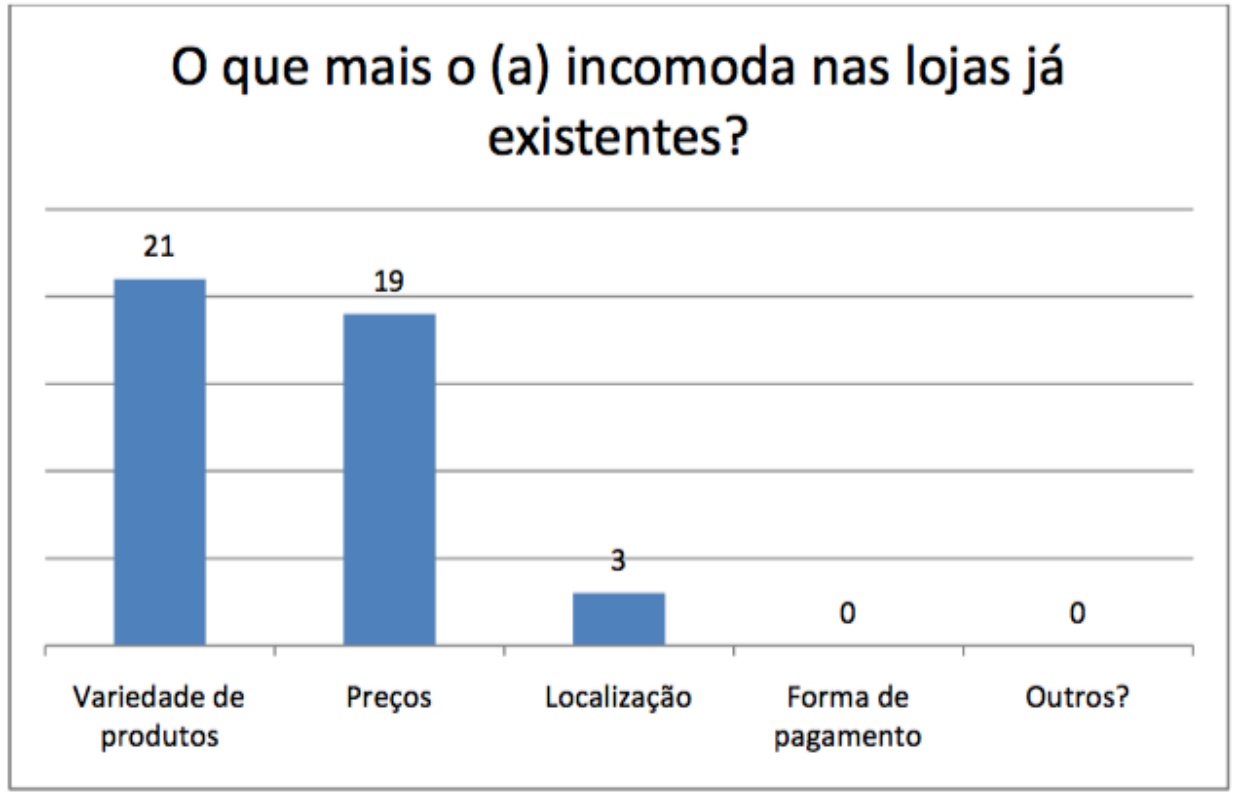


Ao saber o que mais incomoda os clientes, é possível fazer diferente, para melhor atender.

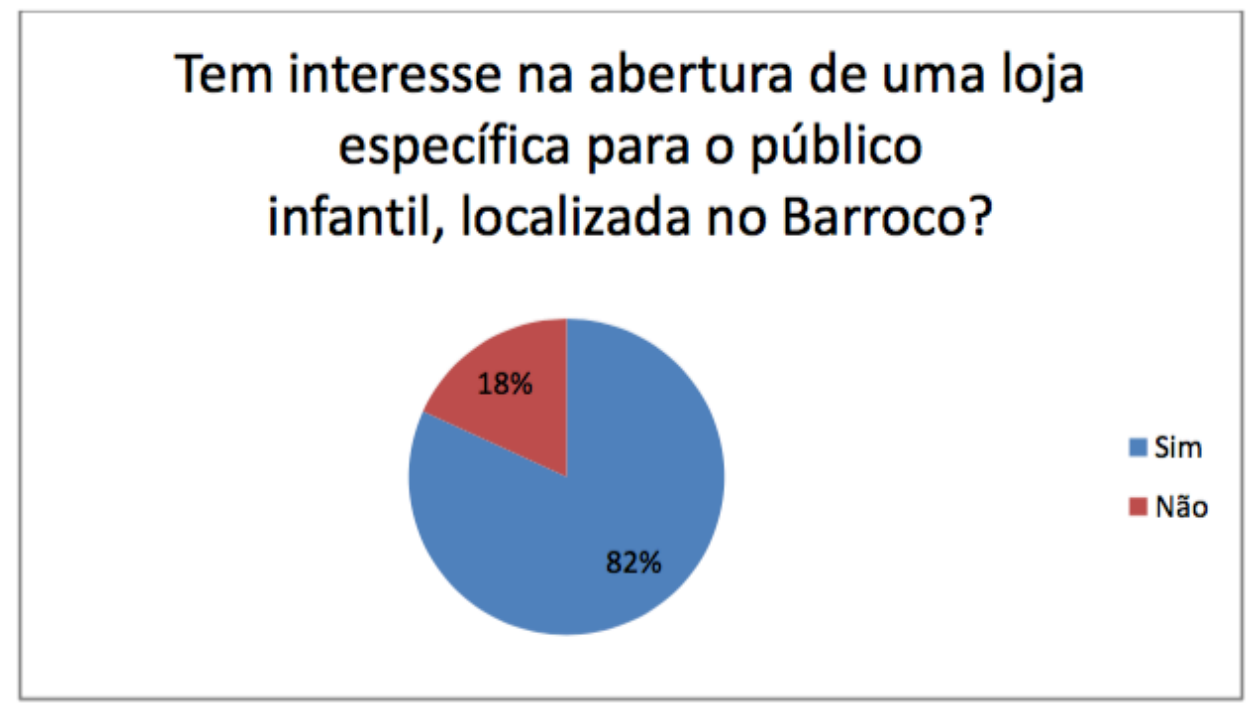

Identificar o interesse do público é de suma importância para saber se o negócio é atrativo.

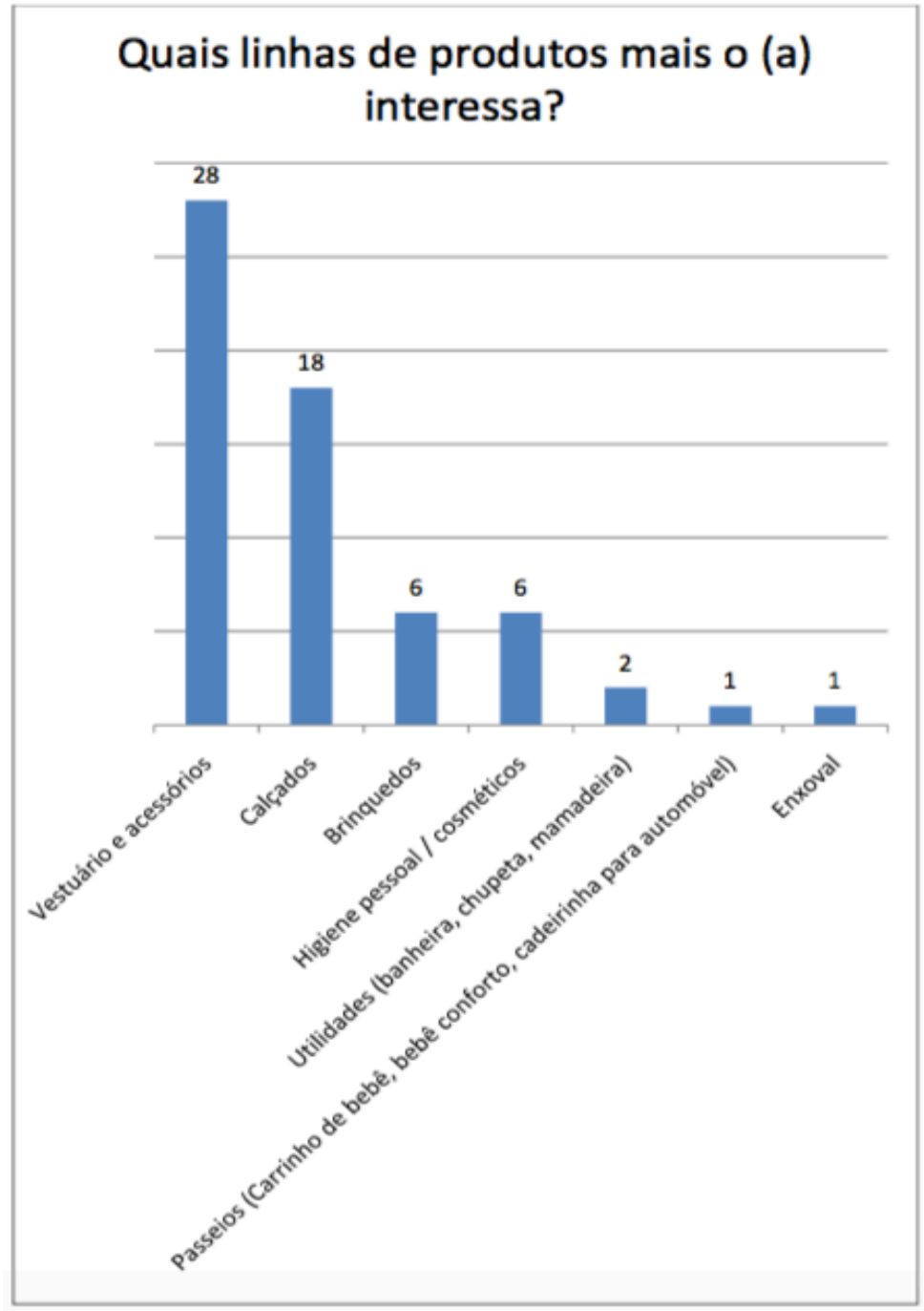


Saber quais produtos os clientes mais buscam ajuda saber em quais suprimentos se deve investir mais.

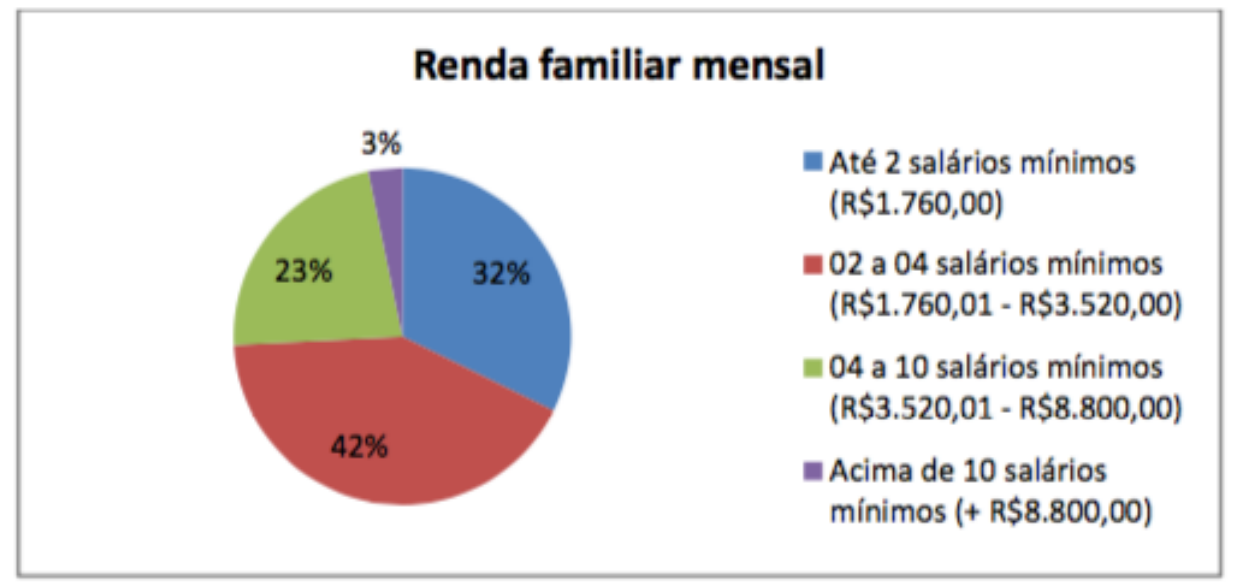

Esta questão nos auxilia a identificar qual faixa de renda devemos priorizar enquanto público-alvo.

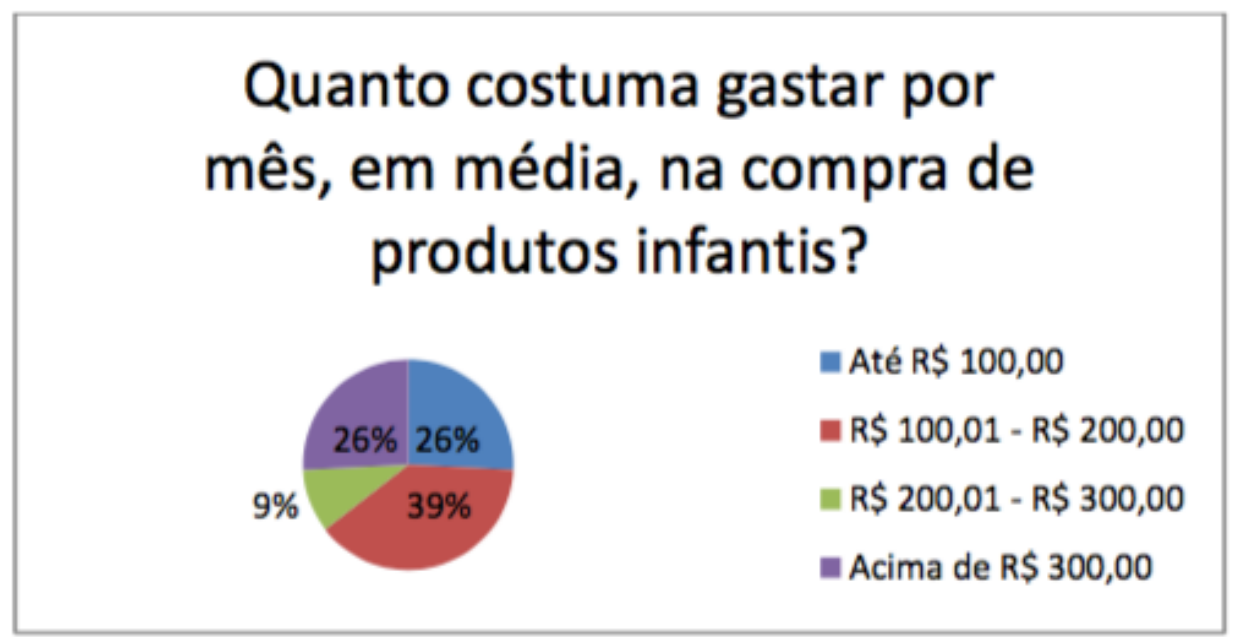

Aqui temos uma idéia do valor gasto mensalmente pelas famílias com aquisição de produtos para suas crianças.

\section{Tem interesse na oferta de serviço delivery (entrega em sua residência)?}

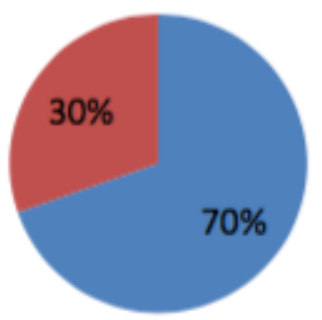

= Sim

" Não 
Considerando ofertar um diferencial aos clientes, saber se eles tem interesse se faz importante.

\section{Barreiras à entrada de novos competidores}

Uma loja de roupas e artigos infantis estruturada da maneira que se planeja aqui, não tem concorrência do mesmo nível em Itaipuaçu, porém é facilmente encontrada em cidades próximas, como Maricá e Niterói, bem como há 0 advento das vendas e-commerce.

Sendo assim, sabemos serem baixas as barreiras de entrada a novos competidores. Cientes disso, a proposta que entra no mercado diferenciada, precisará se manter sempre à frente. Visa-se então, além da estrutura, oferta de ampla gama de produtos, ambiente agradável e atrativo ao público, atendimento especializado; desenvolver trabalho de MKT/divulgação, com carro de som, atrações chamariz na frente de loja esporadicamente (carrinho de pipoca, algodão doce, picolé, palhaço, personagens conhecidos das crianças), preços atrativos (abaixo do praticado em concorrentes que ofertem os mesmos produtos, evitando assim que os clientes queiram sair de seu bairro para consumir) com produtos de qualidade, desenvolver perfis em redes sociais, criar site e posteriormente realizar vendas e-commerce, e ainda, ofertar serviço delivery inicialmente dentro do município, com projeção de expandir aos municípios vizinhos 4 .

\section{Descrição do público-alvo}

Conforme já mencionado em outros tópicos, o público de interesse são as famílias de Itaipuaçu, pertencentes às classes $C$ e $D$, podendo eventualmente atender a classe $B$. $O$ público usuário são crianças, de ambos os sexos, na faixa etária de 0 a 14 anos.

\section{Estratégias de segmentação do mercado}

A ampla oferta de produtos proposta pela loja visa atender diferentes segmentos de mercado infantil, atendendo necessidades de vestuário, enxoval, passeio e utilidades, brinquedos, calçados, produtos de higiene pessoal e cosméticos, ao público de 0-14 anos, dos sexos masculino e feminino. Ofertando marcas conhecidas e prezando sempre a qualidade.

\section{Análise da concorrência}

Em âmbito local, é possível identificar 4 pequenas lojas, estabelecidas distantes do grande centro comercial do bairro e ainda com baixa oferta de produtos, pouco divulgadas e preços altos, o que faz com que 0 morador local saia de seu município/bairro, para adquirir produtos para suas crianças em municípios vizinhos. Além destas, existe uma grande loja, bem localizada, voltada ao público adulto, que também oferta roupas infantis.

São as principais concorrentes locais: Vira Moda Kids, Pingo de Mel, Ciranda Kids e Virou Mania Baby. Ainda, com pouquíssima oferta ao público infantil, podemos mencionar a Abutre. Cabe ainda aqui ressaltar a forte concorrência do mercado online no setor.

Seguem mais detalhes sobre as concorrentes lojas físicas locais:

\footnotetext{
${ }^{4}$ https://endeavor.org.br/por-que-e-como-criar-barreiras-de-entradapor-que-e-como-criar-barreiras-de-entrada/
} 


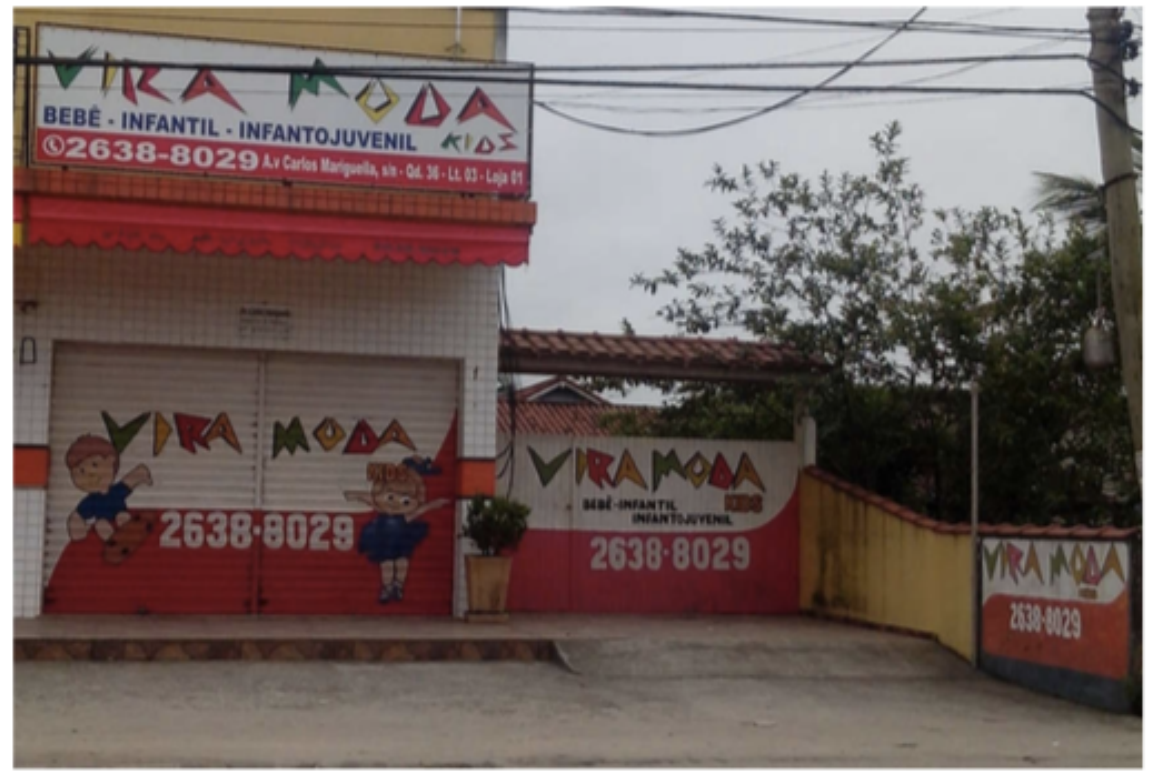

A Vira Moda Kids é a concorrente mais próxima da proposta Kids Açu, porém não oferta uma gama tão vasta de linhas de produtos, encontra-se afastada do grande centro comercial e não investe em divulgação, contando ainda com a oferta de produtos pouco reconhecidos e altos preços.

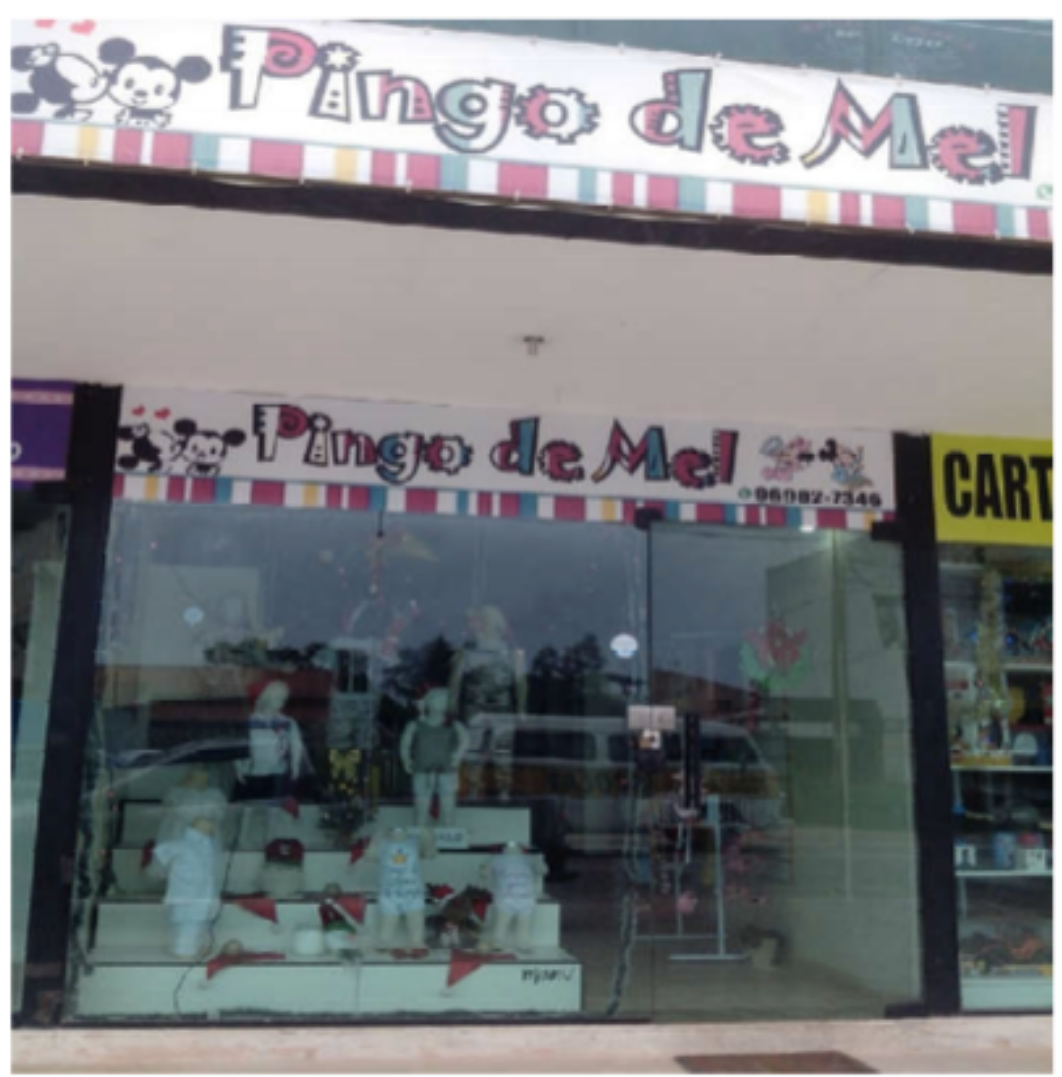

A Pingo de Mel encontra-se super afastada do grande centro comercial, é pequena, possui pouca variedade de produtos e não investe em divulgação, seus preços também são elevados. 


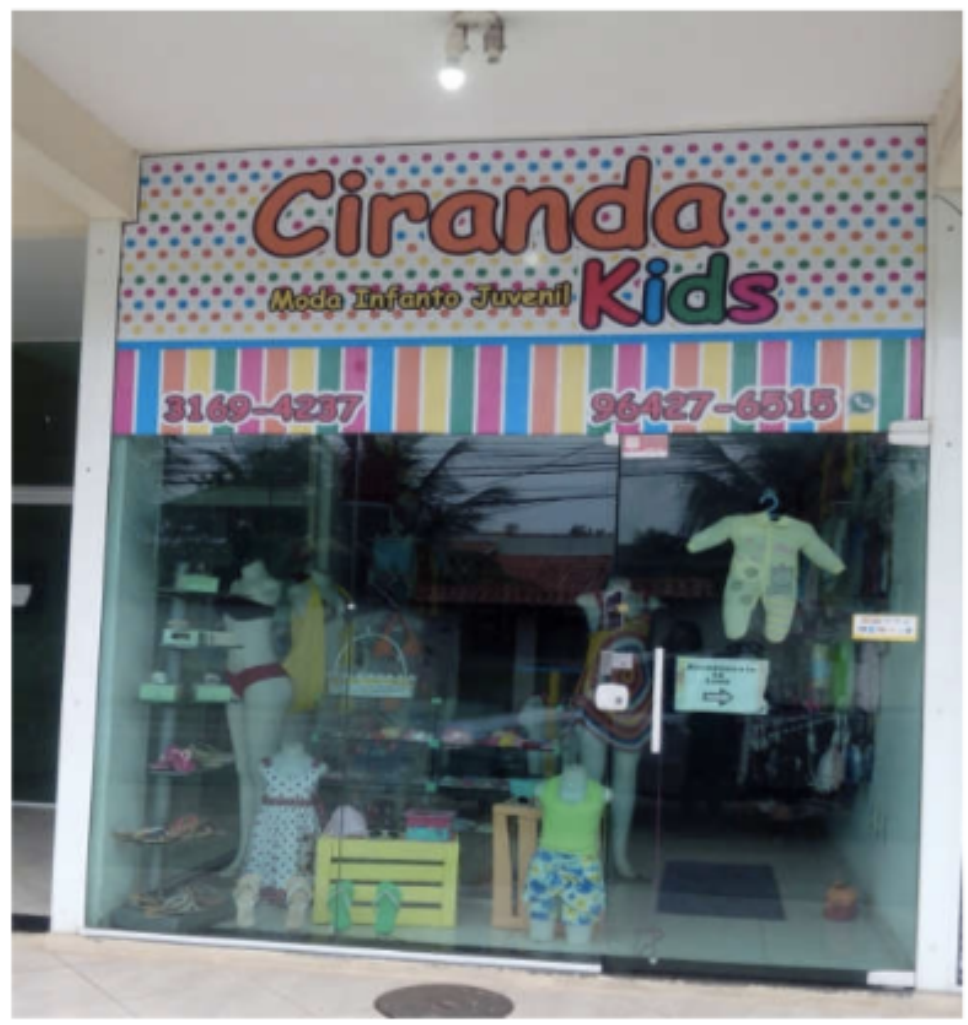

A Ciranda Kids encontra-se em local afastado do grande centro comercial, porém de ampla circulação de pessoas, sendo super visível. Sua estrutura é pequena, com pouquíssima oferta de produtos, baixa qualidade, e ainda tem 0 agravante de mesclar moda adulta com infantil. Apresenta preços populares.

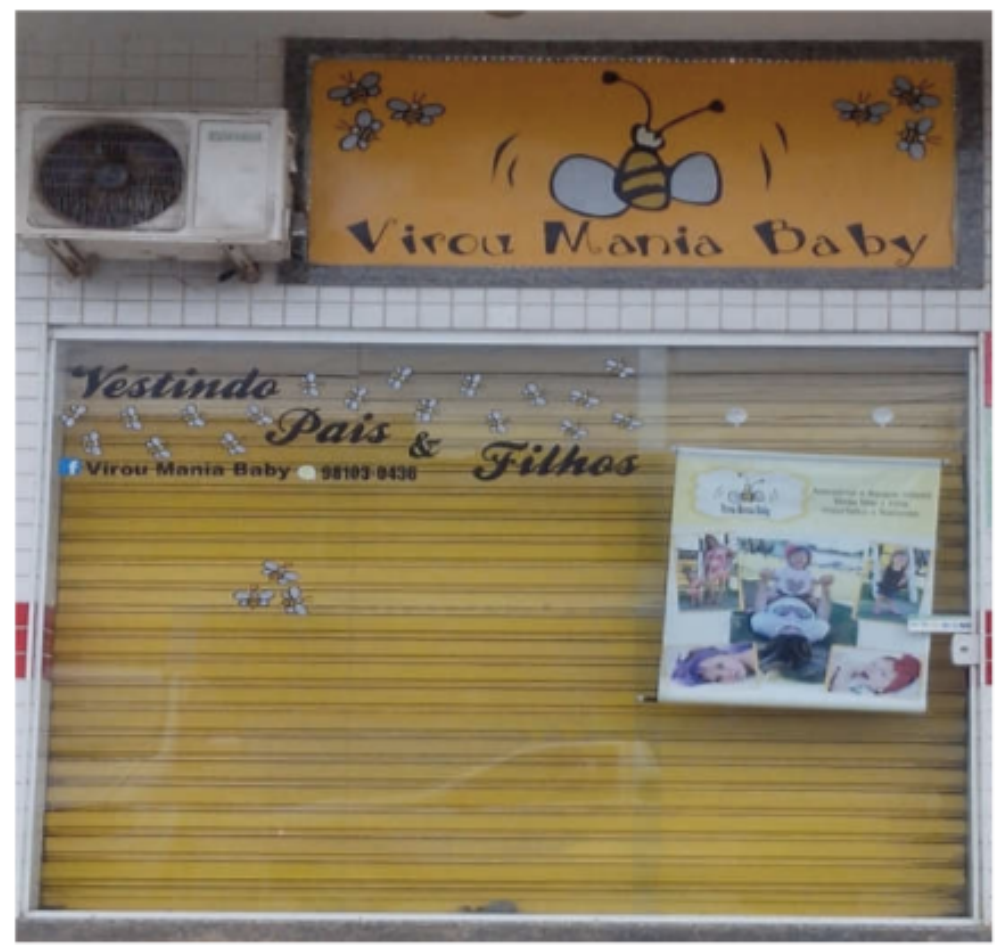


A Virou Mania Baby também encontra-se afastada do grande centro comercial e possui estrutura pequena, com poucas linhas de produtos, porém investe em divulgação frente de loja com atrações para crianças, propaga promoções. Está mais voltada ao público da primeira infância (0-5 anos). Possuem uma proposta interessante de vender casado roupa adulto e infantil, combinando pais e filhos.

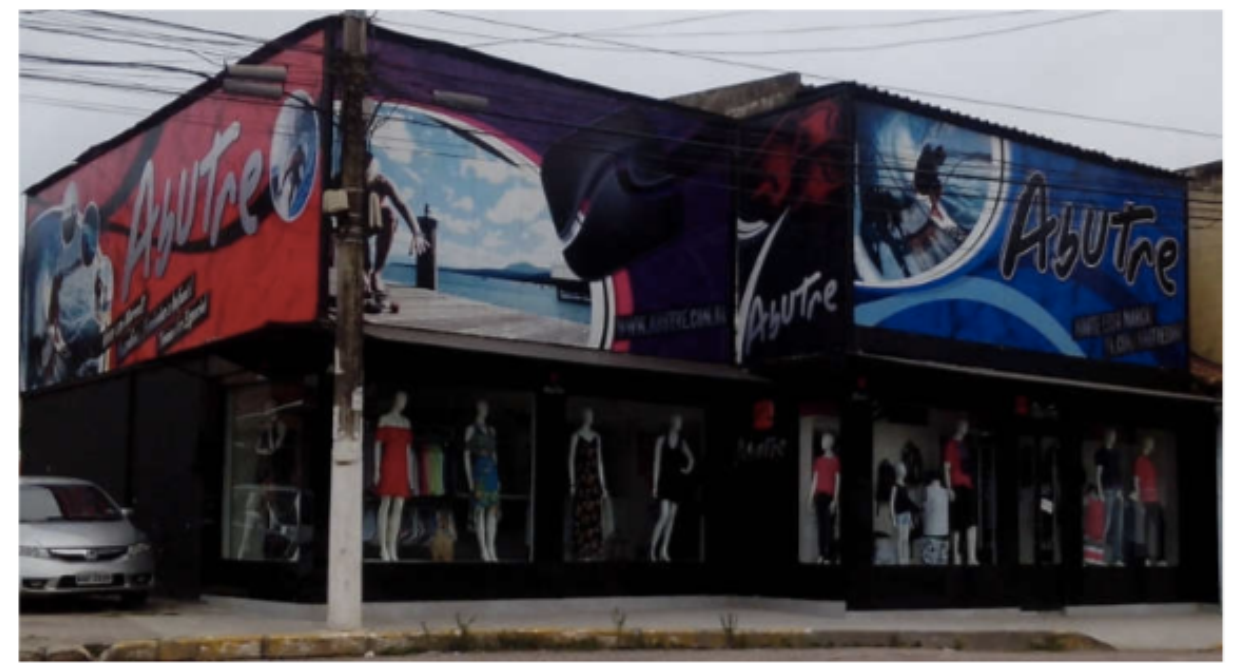

A Abutre é uma grande loja, bem localizada (próximo de onde será aberta a Kids Açu), bem divulgada e reconhecida, porém seu público alvo são adultos, contando também com linhas infanto-juvenil. Não está sendo caracterizada como uma concorrente importante, mas vale levar em consideração.

\section{Descrição dos possíveis fornecedores}

A contratação de fornecedores visa atender ao exposto no tópico sobre segmentação de mercado, e para isso, busca-se realizar pesquisas por fornecedores reconhecidos no mercado, com interesse inicial de comprar o valor mínimo possível da maior gama de fornecedores.

Objetiva-se contactar revendedor que oferte diferentes marcas, possibilitando a compra mesclada das mesmas. Essa pesquisa deve indicar a melhor forma de compra no quesito custo.

Visita ao Brás, em São Paulo, deverá ser realizada, tendo em vista ser local atrativo aos lojistas do segmento de moda. Bem como, serão realizadas visitas à feiras voltadas ao público infantil, para conhecimento das tendências e condições de negócios para eventual compra de produtos.

Vale destacar algumas marcas (por segmento):

- No segmento de vestuário e acessórios, são marcas de interesse: Brandili, Elian, Kyly, Colorittá, Marisol, Malwee, Hello Kitty, Milon, Kiko e Kika, Dibambini, D-Tuia Baby, Lucca Kids, Pinoti Baby, Lolita, Baby Mania, Lenita Baby, Tricae, Lilica Ripilica, Tip Top.

- No segmento de calçados, são marcas de interesse: Tricae, Pimpolho, Sonho de crianças (sapatos sociais), Lilica Ripilica, Kidy calçados infantis, Xuá Xuá, Puma tênis infantil, Converse Tênis Star, Molekinha, Pé com Pé (papete neném), Tip Top.

- No segmento de enxoval, são marcas de interesse: Papi, Medina confecções, Lenita Baby.

- No segmento de passeio e utilidades, são marcas de interesse: Baby Mania, Kuka, Nenê Belo, Fofokit's, Klin.

- No segmento de brinquedos, são marcas de interesse: Baby Mania, Tricae, Klin 
- No segmento de produtos de higiene pessoal e cosméticos, são marcas de interesse: Baby mania,Johnson e Johnson, Huggies Turma da Mônica, Baruel Turma da Xuxinha, Pampers.

\section{Plano Estratégico}

Missão: Atender às necessidades dos nossos clientes, com variedade em roupas e artigos infantis, primando pela qualidade, excelência no atendimento e bom preço, para região de Itaipuaçu e arredores.

Visão: Ser reconhecida em Itaipuaçu, no prazo máximo de dois anos, como uma loja atrativa, que supre as expectativas dos clientes, proporcionando encantamento e satisfação. Em longo prazo, buscar novas praças e realizar vendas e-commerce para outras regiões do país, com igual reconhecimento.

\section{Valores:}

- Ambiente agradável, organizado e atrativo;

- Foco no cliente;

- Prazer em atender;

- Clareza e verdade nas negociações;

- Produtos de qualidade com marcas reconhecidas;

- Melhores preços do mercado;

- Preocupação social;

- Inovação em dinâmicas de MKT e venda.

\section{Análise SWOT}
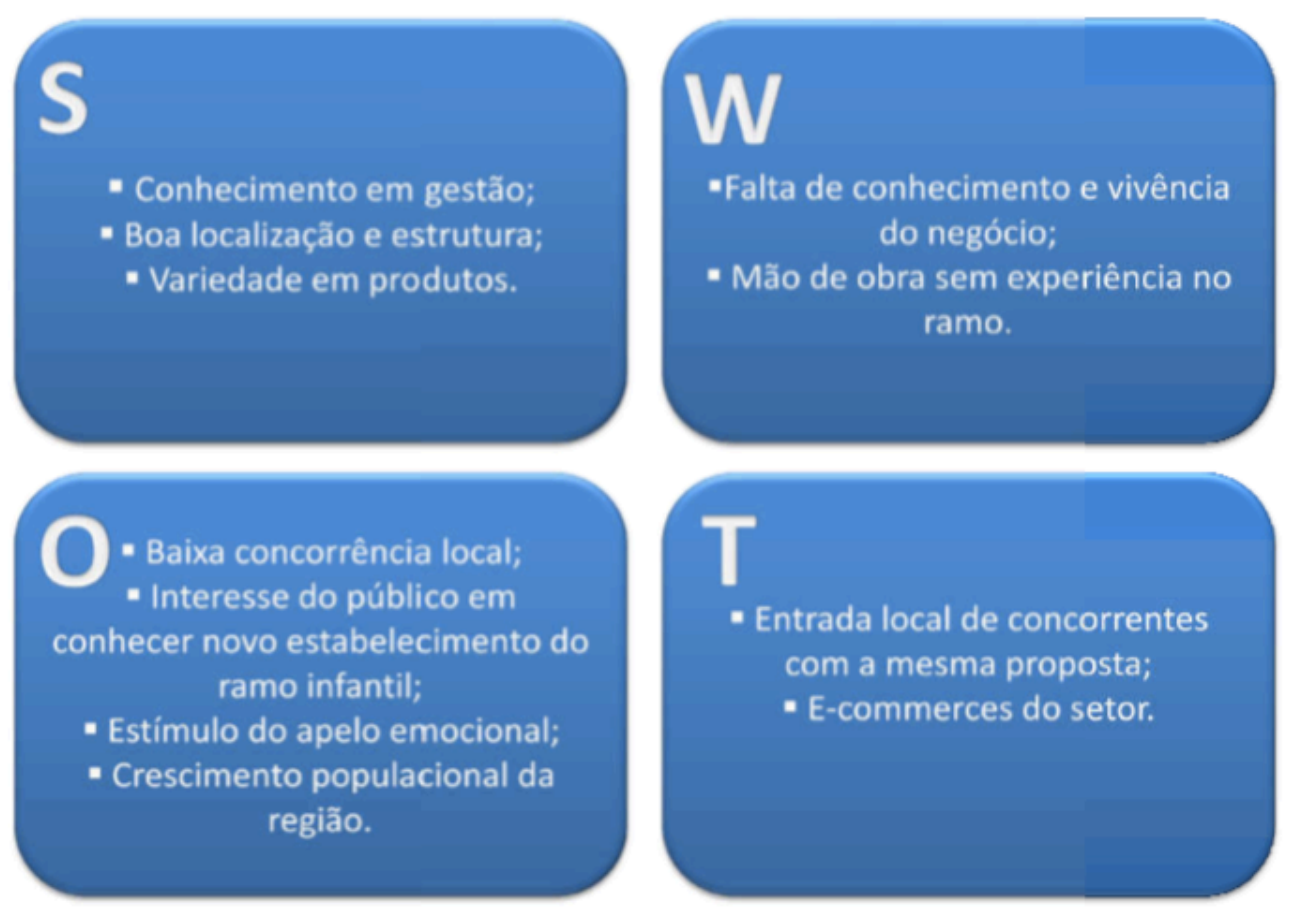
Objetivos, metas e indicadores

\begin{tabular}{|c|c|c|}
\hline Objetivos & Metas & Indicadores \\
\hline \multirow{3}{*}{$\begin{array}{l}\text { Liderar o comércio de } \\
\text { roupas e artigos infantis } \\
\text { em Itaipuaçu. }\end{array}$} & $\begin{array}{l}\text { Aumentar número de } \\
\text { vendas gradativamente: } \\
\text { Vender em média } \\
\text { R\$46.600 nos dois } \\
\text { primeiros meses; } \\
\text { R\$139.800 no primeiro } \\
\text { semestre; e R } \$ 311.400 \\
\text { até o final do primeiro } \\
\text { ano. }\end{array}$ & $\begin{array}{l}\text { Relatórios de caixa no } \\
\text { decorrer dos períodos }\end{array}$ \\
\hline & $\begin{array}{l}\text { Ser reconhecida como a } \\
\text { melhor loja do segmento } \\
\text { infantil no comércio local } \\
\text { ao longo de um ano }\end{array}$ & $\begin{array}{c}\text { Pesquisa no bairro ao } \\
\text { final do primeiro ano }\end{array}$ \\
\hline & $\begin{array}{l}\text { Ampliar número de } \\
\text { clientes em pelo menos } \\
100 \% \text { do primeiro para o } \\
\text { segundo ano e assim } \\
\text { consecutivamente }\end{array}$ & Cadastro de clientes \\
\hline
\end{tabular}

\section{Ações estratégicas:}

Tendo em vista o objetivo geral de liderar o comércio de roupas e artigos infantis em Itaipuaçu, visando se consolidar no mercado local no prazo máximo de dois anos estabelece-se as seguintes ações estratégicas:

\section{Capacitaçāo de funcionários}

\section{O quê? (WHAT) \\ Quem? (WHO)}

Onde? (WHERE)

Quando? (WHEN)

Por quê? (WHY)

Como? (HOW)

Quanto? (HOW MUCH)
Conferir à equipe treinamentos, para aquisição de conhecimentos técnicos que melhorem sua capacidade produtiva e desempenho

\section{Empreendedor}

No interior da loja; e ainda inscrevendo em cursinhos, palestras e promovendo participação em feiras do setor

\section{Eventualmente}

Confere ganhos de rendimentos à empresa e motiva funcionários

Contratação de profissional do ramo para promover dinâmicas e treinamento em vendas; passar vídeos sobre produtos de fornecedores e promover discussões sobre os mesmos; inscrição e custeio para participação em cursinhos, palestras e eventos que agreguem conhecimento $e$ valor às atividades

Anualmente estima-se um custo aproximado de $\mathrm{R} \$ 1.000$ (mil reais) para tais práticas 


\section{Investimento em divulgação da loja}

\begin{tabular}{l}
\hline quê? (WHAT) \\
\hline Quem? (WHO) \\
\hline
\end{tabular}

\begin{tabular}{l}
\hline Onde? (WHERE) \\
\hline Quando? (WHEN) \\
\hline Por quê? (WHY) \\
\hline
\end{tabular}

Como? (HOW)

Quanto? (HOW MUCH)
Promoção de ações convidativas

\section{Empreendedor}

Frente de loja, ruas do bairro, internet, impressos locais e panfletos

Periodicamente, priorizando períodos sazonais

Porque divulga, torna a loja conhecida

Carro de som, eventos temáticos (Papai Noel, personagens de desenhos infantis, coelho da páscoa, entre outros), chamariz no ponto de venda para crianças (carro de pipoca, algodão doce, picolé), além das tradicionais mídias impressas e digitais

Mensalmente estima-se um custo aproximado de $\mathrm{R} \$ 1.500$ (mil e quinhentos reais) para tais práticas

\section{Oferta de ampla gama de produtos}

\begin{tabular}{|l|l|}
\hline O quê? (WHAT) & $\begin{array}{l}\text { Disponibilizar variedade de produtos para } \\
\text { comercialização }\end{array}$ \\
\hline Quem? (WHO) & Empreendedor com auxílio da equipe de loja \\
\hline Onde? (WHERE) & Interior da loja \\
\hline Quando? (WHEN) & Sempre \\
\hline Por quê? (WHY) & Atrai clientes, torna loja interessante \\
\hline Como? (HOW) & $\begin{array}{l}\text { Aquisição e disposição de produtos de diferentes } \\
\text { linhas (vestuário, calçados, acessórios, enxoval, } \\
\text { cosméticos e higiene pessoal, passeios e utilidades) } \\
\text { para atendimento ao público infantil de 0-14 anos }\end{array}$ \\
\hline Quanto? (HOW MUCH) & $\begin{array}{l}\text { Para abertura da loja estima-se um investimento de } \\
\text { R\$̧60.000 (sessenta mil reais) em produtos }\end{array}$ \\
\hline
\end{tabular}


Traçado o plano de ação descritos nas planilhas acima (formulação de estratégias), estabelece-se uma matriz GUT, para identificar a priorização das atividades descritas.

A - Capacitação de funcionários

B - Investimento em divulgação da loja

C - Oferta de ampla gama de produtos

\begin{tabular}{|c|c|c|c|c|c|}
\hline $\begin{array}{c}\text { Atividade ou } \\
\text { Problema }\end{array}$ & G & U & T & TOTAL & Priorizaçäo \\
\hline A & 3 & 3 & 1 & 9 & $3^{\circ}$ \\
\hline B & 5 & 4 & 5 & 100 & $2^{\circ}$ \\
\hline C & 5 & 5 & 5 & 125 & $1^{\circ}$ \\
\hline
\end{tabular}

Gravidade (G) - Impacto sobre a organização; Urgência (U) - Tempo disponível; Tendência (T) Probabilidade de piorar.

Modelo de negócio

\section{CANVAS}

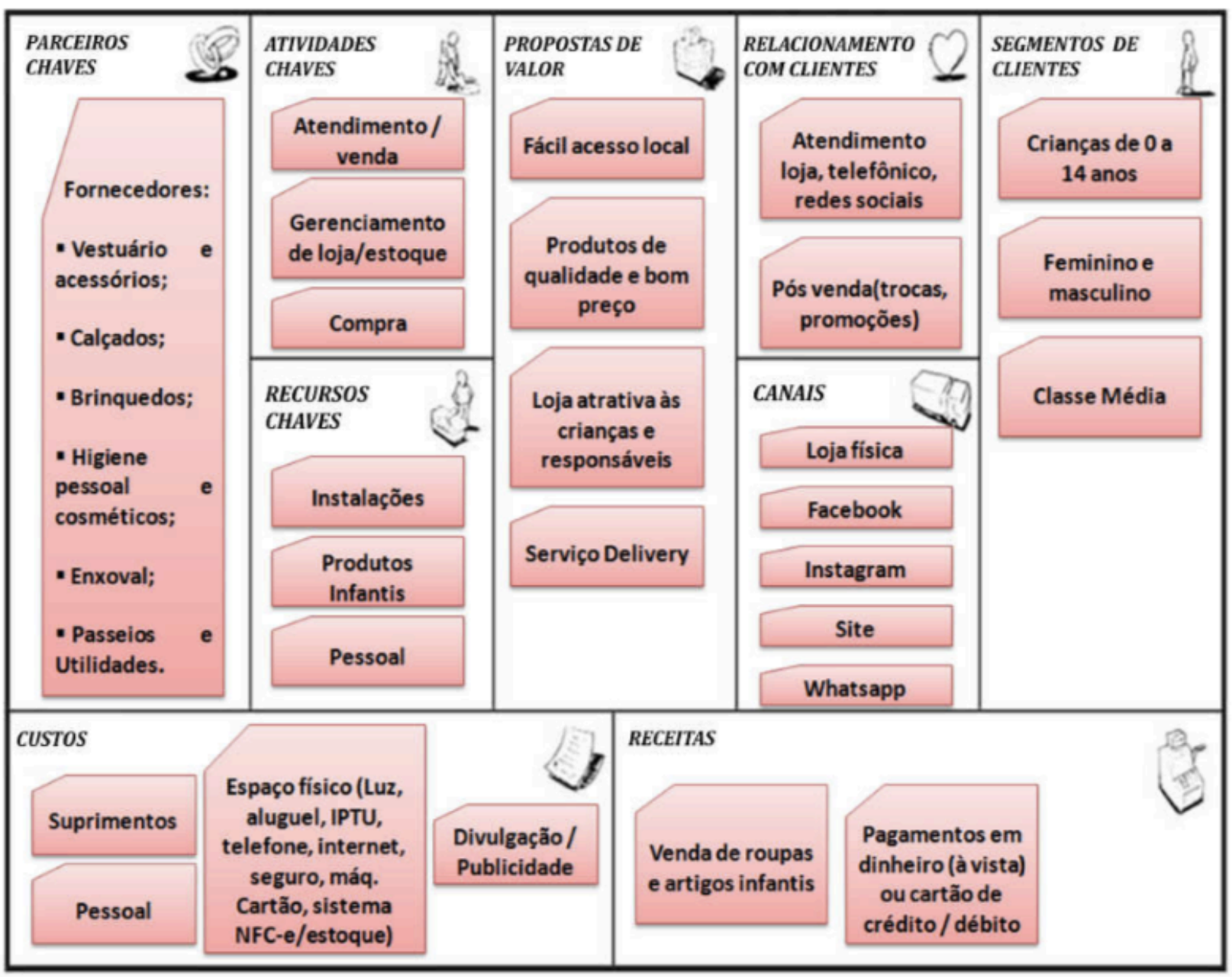




\section{Marketing e Vendas}

\section{Descrição detalhada dos produtos}

Baseando-se nas linhas de produtos a serem vendidas, seguem descrições:

Vestuário e acessórios: Para bebês (0 a 12 meses) de ambos os sexos teremos bodies e macacões, conjuntos, camisetas e blusas, bermudas, shorts, calças, pijamas, casacos, jardineiras, pólo, vestidos, saídas de maternidade, moda praia, babador, laços, meias, calcinhas e cuecas;

Para fase de 1 a 3 anos, de ambos os sexos, teremos bodies e macacões, conjuntos, camisetas e blusas, bermudas, shorts, calças, pijamas, casacos, jardineiras, pólos, regatas, vestidos, moda praia, babador, laços, bonés, meias, calcinhas e cuecas;

Para fase de 4 a 14 anos, de ambos os sexos, teremos macacões, macaquinhos, conjuntos, camisetas e blusas, bermudas, shorts, calças, pijamas, camisolas, casacos, jaquetas, jardineiras, pólos, regatas, vestidos, leggings, coletes, boleros, blusões, moda praia, laços, bonés, meias, calcinhas e cuecas, bolsas;

Vale mencionar que teremos vestimentas em moleton, cotton, microfibra, jeans, algodão, tecido. Primamos pela qualidade, e por isso buscamos produtos de marcas reconhecidas já descritas no tópico sobre fornecedores.

Calçados: Teremos calçados para o público de 0 a 14 anos, contando com tênis, sapatênis, sapatinhos, sapatilhas, sandálias, botas, chinelos, coturnos, mocassins.

As marcas de pretensão para trabalhar encontram-se descritas no tópico sobre fornecedores.

Enxoval: Teremos roupas de cama, kit berço, rolinhos segura bebê, porta fraldas. As marcas de pretensão para trabalhar encontram-se descritas no tópico sobre

fornecedores.

Passeio e utilidades: Teremos banheiras, mamadeiras, chupetas, copos, pratos, talheres, garrafas, bolsas de bebê, bebê conforto, cadeirinha para automóvel, carrinhos de bebê.

As marcas de pretensão para trabalhar encontram-se descritas no tópico sobre fornecedores.

Brinquedos: Aqui pensamos em atender apenas o público de 0 a 3 anos, com poucas ofertas. Sendo assim, teremos chocalhos, tapete tatame, mobílies, mordedores, alguns brinquedos sonoros.

As marcas de pretensão para trabalhar encontram-se descritas no tópico sobre fornecedores.

Higiene pessoal e cosméticos: Teremos a oferta de kits higiene (tesourinha de cortar unha, escova e pente de cabelo), toalhas de banho com capuz, fraldas RN, P, M e G, lenços umedecidos, shampoo e condicionador, sabonetes, colônias, protetor solar infantil, cremes/pomadas para prevenção de assaduras, cotonetes.

As marcas de pretensão para trabalhar encontram-se descritas no tópico sobre fornecedores.

\section{Descrição da inovação trazida pela empresa}

A princípio podemos dizer que a inovação está na própria proposta de abertura da loja na localidade prevista, já que não há presença de estabelecimento com as mesmas características e proposição de valores. Porém, sabemos serem baixas as barreiras à entrada de novos competidores, e sendo assim, buscamos inovação em processos, de forma incremental. Temos então, mudança na forma como os produtos/serviços são introduzidos, fazendo o que já se sabe, porém aperfeiçoando da melhor forma.

A priori, pensamos para além da estrutura, oferta de ampla gama de produtos, ambiente agradável e atrativo ao público, atendimento especializado; desenvolver trabalho de MKT/divulgação, com carro de som, atrações chamariz na frente de loja esporadicamente (carrinho de pipoca, algodão doce, picolé, palhaço, 
personagens conhecidos das crianças), preços atrativos com produtos de qualidade, desenvolver perfis em redes sociais, criar site e posteriormente realizar vendas e-commerce, e ainda, ofertar serviço delivery inicialmente dentro do município, com projeção de expandir aos municípios vizinhos, e ainda promoção de oferta social arrecadando roupas usadas e oferecendo descontos.

Vale ressaltar a ciência de que é preciso estar sempre atento às movimentações do mercado e buscar atualizações e aperfeiçoamentos constantes, de forma a se manter sempre em posição de destaque.

\section{Formas de evitar imitações}

No caso da loja de roupas e artigos infantis em Itaipuaçu, onde não há uma concorrente com mesma estrutura e ofertas, esta sai à frente em seu processo de inovação e vantagens competitivas. Evitar imitações aqui é processo constante de estar à frente promovendo atratividade e consolidando nome na localidade.

\section{Evolução prevista do produto - pesquisa e desenvolvimento}

Por não ter característica de produzir, mas sim de revender produtos adquiridos de terceiros, cabe neste ponto apenas atentar às tendências do mercado, visitando feiras do setor, consultando revistas e afins, no intuito de estar sempre trazendo produtos em alta tendência para a loja, e assim realizar divulgações chamariz.

\section{Comparação com produtos substitutos e/ou concorrentes}

Acreditamos aqui ser importante a preocupação com concorrentes que promovem vendas e-commerce, pois estes têm ofertas variadas a preços sempre mais atrativos que as lojas físicas. Nesta modalidade é possível encontrar todas as linhas de produtos que se pretende trabalhar, bem como as marcas. Assim como teremos produtos fáceis de serem encontrados em estabelecimentos específicos, como farmácias/drogarias, supermercados, sapatarias, lojas de brinquedos e até as lojas que comercializam apenas roupas. Em Itaipuaçu não há presença marcante de lojas ofertantes de produtos infantis, tendo em abundância apenas farmácias e mercados/supermercados.

.A proposta da loja única a ofertar variedade de produtos é nova na localidade. Não existindo um concorrente com igual proposta.

\section{Detalhamento da estratégia de entrada no mercado}

Focando no comércio de roupas e artigos infantis em Itaipuaçu, percebeu-se a ausência de uma loja estruturada que promovesse este mercado, sendo assim, a proposta apresentada para entrada neste mercado, tem seu início como novidade à localidade. Como já mencionado em tópicos anteriores, visa-se aqui, a estruturação da loja em espaço adequado, boa localização, ampla oferta de produtos e preços atrativos para penetração no mercado (podendo ir aumentando gradativamente no decorrer da atividade), primaremos por um atendimento de excelência, para que o cliente se sinta a vontade e queira voltar. Em início de operação e constantemente, contaremos com divulgação em massa através de carros de som, panfletagem, banda na frente de loja nos dias inaugurais, além de outras atrações chamariz esporadicamente.

\section{Formação de preço}

Para composição do preço de venda, foi verificado preços praticados no mercado, e então chegou-se a conclusão que seria possível formar o preço aplicando $100 \%$ do custo direto do produto. Desta forma 0 preço fica abaixo do praticado no mercado.

Será adotada prática de descontos para clientes fidelizados que comprem $X$ por mês garantindo assim 0 direito a desconto na próxima compra, e ainda para participantes da campanha desconto solidário, a ser promovida, onde o cliente doa uma roupa usada de seu filho e recebe desconto. A política de descontos da campanha ainda está sendo estruturada.

O pagamento poderá ser feito à vista em dinheiro ou cartão (débito ou crédito), e ainda ser parcelado no 
cartão em até 6 vezes, a depender do valor da compra.

\section{Distribuição}

Localização: Barroco - Itaipuaçu - Maricá/RJ Nível de canal de distribuição: 01 = Fabricante - Varejista Consumidor Tipo de loja: Loja física - Varejista (realiza a venda direta ao consumidor final)

O local escolhido para abertura do negócio é bem movimentado e atrativo, devido à alta rotatividade de pessoas diariamente. Sendo o grande centro comercial do bairro, onde encontram-se outros estabelecimentos que atingem o público de interesse, como clínica com atendimento pediátrico, escolas e cursos de línguas. Adota-se também a interatividade com o serviço delivery.

\section{Promoção}

Os meios de promoção utilizados serão: Espaço físico, Facebook, Instagram, Whatsapp, site, mídias impressas como panfletos, catálogos/revistas locais, carro de som.

\section{Relacionamento com cliente}

Manter bom relacionamento com cliente é o princípio fundamental do negócio. Pensamos neste para todo o processo, desde a prospecção do cliente, venda, fidelização e pós venda. Busca-se trabalhar com empatia, senso de justiça e clareza, sem objetivo de empurrar produto, mas auxiliá-los a atender suas necessidades, buscando sempre ouvi-los para melhor atuar. Serão feitas promoções, informativos pós venda, atender reclamações com prontidão, e ainda através de cadastros, identificar aniversários, parabenizar e oferecer desconto ou brinde via e-mail, Whatsapp ou Facebook.

\section{Investimentos pré-operacionais}

\begin{tabular}{|c|c|c|c|c|}
\hline $\begin{array}{c}\text { Investimentos em obras e instalaçōes } \\
\text { (materiais + M.O.) }\end{array}$ & Período 0 & $\begin{array}{l}\text { Total } \\
\text { ANO } 1\end{array}$ & $\begin{array}{l}\text { Total ANO } \\
\quad 2\end{array}$ & $\begin{array}{c}\text { Total ANO } \\
3\end{array}$ \\
\hline Locação de espaço & $19.000,00$ & 0,00 & 0,00 & 0,00 \\
\hline Reparos e adequações nas partes interna e externa & $9.133,42$ & 0,00 & 0,00 & 0,00 \\
\hline Rebaixo de gesso & $1.500,00$ & 0,00 & 0,00 & 0,00 \\
\hline Vidro temperado frente de loja & $1.328,00$ & 0,00 & 0,00 & 0,00 \\
\hline Vidro temperado como guarda corpo (externo) & 125,95 & 0,00 & 0,00 & 0,00 \\
\hline Colocação de luminárias e instalações elétricas & $1.880,00$ & 0,00 & 0,00 & 0,00 \\
\hline Reparos e adequaçōes na parte hidráulica & 200,00 & 0,00 & 0,00 & 0,00 \\
\hline Fachada $(\mathrm{ACM})+$ Letreiro & $3.655,00$ & 0,00 & 0,00 & 0,00 \\
\hline Pintura externa & $1.343,07$ & 0,00 & 0,00 & 0,00 \\
\hline Pintura interna & $1.400,00$ & 0,00 & 0,00 & 0,00 \\
\hline $\begin{array}{l}\text { Outros (instalação de ares cond., conserto mola } \\
\text { porta,...) }\end{array}$ & $2.450,00$ & 0,00 & 0,00 & 0,00 \\
\hline Total & $42.015,44$ & 0,00 & 0,00 & 0,00 \\
\hline
\end{tabular}


Fabiana da Conceição Mendes

\begin{tabular}{|c|c|c|c|c|}
\hline Aquisição de equipamentos e material permanente & Período 0 & $\begin{array}{l}\text { Total } \\
\text { ANO 1 }\end{array}$ & $\begin{array}{c}\text { Total ANO } \\
2 \\
\end{array}$ & $\begin{array}{c}\text { Total ANO } \\
3 \\
\end{array}$ \\
\hline Manequins & $1.500,00$ & 0,00 & 0,00 & 0,00 \\
\hline Mobiliários & $13.800,00$ & 0,00 & 0,00 & 0,00 \\
\hline Aparelhos de ar condicionado & $4.017,00$ & 0,00 & 0,00 & 0,00 \\
\hline Sistema de segurança & $3.590,00$ & 0,00 & 0,00 & 0,00 \\
\hline Sistema informática & $1.000,00$ & 0,00 & 0,00 & 0,00 \\
\hline Impressora fiscal & $1.150,00$ & 0,00 & 0,00 & 0,00 \\
\hline Leitora laser & 580,00 & 0,00 & 0,00 & 0,00 \\
\hline Computadores & $2.836,00$ & 0,00 & 0,00 & 0,00 \\
\hline Total & $28.473,00$ & 0,00 & 0,00 & 0,00 \\
\hline Legalização & Período 0 & $\begin{array}{l}\text { Total } \\
\text { ANO } 1\end{array}$ & $\begin{array}{c}\text { Total ANO } \\
\mathbf{2} \\
\end{array}$ & $\begin{array}{c}\text { Total ANO } \\
3\end{array}$ \\
\hline Alvará & $1.300,00$ & 0,00 & 0,00 & 0,00 \\
\hline Contrato social / CNPJ & 800,00 & 0,00 & 0,00 & 0,00 \\
\hline JUCERJA & 800,00 & 0,00 & 0,00 & 0,00 \\
\hline Laudo Vigilância Sanitária & 570,00 & 0,00 & 0,00 & 0,00 \\
\hline Laudo Bombeiros & $2.000,00$ & 0,00 & 0,00 & 0,00 \\
\hline Aprovação da Prefeitura para letreiro & $2.000,00$ & 0,00 & 0,00 & 0,00 \\
\hline Total & $7.470,00$ & 0,00 & 0,00 & 0,00 \\
\hline Total & 77.958 .44 & 0,00 & 0,00 & 0,00 \\
\hline
\end{tabular}

\section{Projeção de receitas}

\begin{tabular}{|c|c|c|c|c|c|c|}
\hline \multicolumn{7}{|l|}{ Projeçăo de Vendas } \\
\hline \multicolumn{4}{|c|}{ Quantidade } & Total ANO 1 & Total ANO 2 & Total ANO 3 \\
\hline \multicolumn{4}{|c|}{ Vestuário e acessórios } & 2340 & 3300 & 4500 \\
\hline \multicolumn{4}{|c|}{ Calçados } & 840 & 1320 & 1920 \\
\hline \multicolumn{4}{|c|}{ Enxoval } & 60 & 96 & 120 \\
\hline \multicolumn{4}{|c|}{ Passeios } & 36 & 60 & 96 \\
\hline \multicolumn{4}{|c|}{ Utilidades } & 300 & 450 & 660 \\
\hline \multicolumn{4}{|c|}{ Brinquedos } & 420 & 660 & 900 \\
\hline \multicolumn{4}{|c|}{ Higiene pessoal e cosméticos } & 720 & 1020 & 1320 \\
\hline \multicolumn{4}{|c|}{ Demanda Total -...>> } & 4716 & 6906 & 9516 \\
\hline Preço & Valor & Reajuste anual & \multirow{8}{*}{$\begin{array}{l}\text { Receita de } \\
\text { Vendas }\end{array}$} & Total ANO 1 & Total ANO 2 & Total ANO 3 \\
\hline Vestuário e acessórios & 70 & $10 \%$ & & $163.800,00$ & $254.100,00$ & $381.150,00$ \\
\hline Calçados & 80 & $10 \%$ & & $67.200,00$ & $116.160,00$ & $185.856,00$ \\
\hline Enxoval & 200 & $10 \%$ & & $12.000,00$ & $21.120,00$ & $29.040,00$ \\
\hline Passeios & 300 & $10 \%$ & & $10.800,00$ & $19.800,00$ & $34.848,00$ \\
\hline Utilidades & 50 & $10 \%$ & & $15.000,00$ & $24.750,00$ & $39.930,00$ \\
\hline Brinquedos & 50 & $10 \%$ & & $21.000,00$ & $36.300,00$ & $54.450,00$ \\
\hline $\begin{array}{l}\text { Higiene pessoal e } \\
\text { cosméticos }\end{array}$ & 30 & $10 \%$ & & $21.600,00$ & $33.660,00$ & $47.916,00$ \\
\hline \multicolumn{4}{|c|}{ Total de Vendas } & $311.400,00$ & $505.890,00$ & $773.190,00$ \\
\hline
\end{tabular}


Projeção de custos e despesas

\begin{tabular}{|c|c|c|c|}
\hline \multicolumn{4}{|l|}{ Projecalo de custos } \\
\hline Custos com produtos & Total ANO 1 & Total ANO 2 & Total ANO 3 \\
\hline Vestuário e acessórios & $81.900,00$ & $127.050,00$ & $190.575,00$ \\
\hline Calçados & $33.600,00$ & $58.080,00$ & $92.928,00$ \\
\hline Enxoval & $6.000,00$ & $10.560,00$ & $14.520,00$ \\
\hline Passeios & $5.400,00$ & $9.900,00$ & $17.424,00$ \\
\hline Utilidades & $7.500,00$ & $12.375,00$ & $19.965,00$ \\
\hline Brinquedos & $10.500,00$ & $18.150,00$ & $27.225,00$ \\
\hline Higiene pessoal e cosméticos & $10.800,00$ & $16.830,00$ & $23.958,00$ \\
\hline Total & $155.700,00$ & $252.945,00$ & $386.595,00$ \\
\hline Total & $155.700,00$ & $252.945,00$ & $386.595,00$ \\
\hline
\end{tabular}

Custo com profissionais (seus funcionários diretamente envolvidos com a produçāo dos bens ou serviços)

\begin{tabular}{|c|c|c|c|c|c|c|c|}
\hline $\begin{array}{c}\text { Tipo de } \\
\text { profissional }\end{array}$ & $\begin{array}{c}\text { Custo } \\
\text { mensal? }\end{array}$ & Salário & $\begin{array}{c}\text { \% de } \\
\text { encargos }\end{array}$ & Quantidade & $\begin{array}{c}\text { Total ANO } \\
1 \\
\end{array}$ & $\begin{array}{c}\text { Total ANO } \\
2 \\
\end{array}$ & $\begin{array}{l}\text { Total } \\
\text { ANO } 3\end{array}$ \\
\hline Gerente & Sim & $2.000,00$ & $21,00 \%$ & 1 & \multirow{2}{*}{$\begin{array}{l}31.040,00 \\
23.376,00\end{array}$} & \multirow{2}{*}{$\begin{array}{l}33.442,40 \\
24.818,40\end{array}$} & \multirow{2}{*}{$\begin{array}{l}35.844,80 \\
26.260,80\end{array}$} \\
\hline Vendedora & Sim & $1.200,00$ & $54,00 \%$ & 1 & & & \\
\hline $\begin{array}{c}\text { Total de Custos } \\
\text { com Pessoal }\end{array}$ & & & & & $54.416,00$ & $58.260,80$ & $62.105,60$ \\
\hline
\end{tabular}

\begin{tabular}{|c|c|c|c|c|c|c|}
\hline Tipo de profissional & Salário & $\%$ de encargos & Quantidade & Total ANO 1 & Total ANO 2 & Total ANO 3 \\
\hline Limpeza interna & 200,00 & $0 \%$ & 1 & $2.600,00$ & $2.842,40$ & $3.084,80$ \\
\hline Limpeza externa & 100,00 & $0 \%$ & 1 & $1.300,00$ & $1.422,40$ & $1.544,80$ \\
\hline \multicolumn{4}{|c|}{ Total de Despesas com Pessoal } & $3.900,00$ & $4.264,80$ & $4.629,60$ \\
\hline
\end{tabular}


Projeclio das Despesas Gorais

\begin{tabular}{|c|c|c|c|c|c|}
\hline Administrativas e de escritório & Item mensal? & Valor mensal & Total ANO 1 & Total ANO 2 & Total ANO 3 \\
\hline Aluguel & Sim & $2.000,00$ & $24.000,00$ & $26.400,00$ & $28.800,00$ \\
\hline IPTU & Sim & 32,00 & 384,00 & 422,40 & 460,80 \\
\hline Luz & Sim & 450,00 & $5.400,00$ & $5.940,00$ & $6.480,00$ \\
\hline Tel. Fixo & Sim & 70,00 & 840,00 & 924,00 & $1.008,00$ \\
\hline Celular & Sim & 32,00 & 384,00 & 422,40 & 460,80 \\
\hline Materiais de escritório & & & 90,00 & 100,00 & 120,00 \\
\hline Total & & & $31.008,00$ & $34.108,80$ & $37.209,60$ \\
\hline
\end{tabular}

Marketing e comercializaçăo Item mensal? Valor mensal Total ANO 1 Total ANO 2 Total ANO 3

\begin{tabular}{|c|c|c|c|c|c|}
\hline Atraçōes frente de loja & & & 800,00 & $1.000,00$ & $1.000,00$ \\
\hline Adesivos painel frente loja & & & 450,00 & 300,00 & 450,00 \\
\hline Lonas laterais da loja & & & 250,00 & 250,00 & 300,00 \\
\hline Panfletos & Sim & 270 & $3.240,00$ & $3.564,00$ & $3.888,00$ \\
\hline Midias impressas locais & Sim & 100 & $1.200,00$ & $1.320,00$ & $1.440,00$ \\
\hline Balōes para crianças (logo loja) & Sim & 225 & $2.700,00$ & $2.970,00$ & $3.240,00$ \\
\hline Carro de som & Sim & 600 & $7.200,00$ & $7.920,00$ & $8.640,00$ \\
\hline Total & & & $15.840,00$ & $17.324,00$ & $18.958,00$ \\
\hline Serviços de terceiros & Item mensal? & Valor mensal & Total ANO 1 & Total ANO 2 & Total ANO 3 \\
\hline Internet & Sim & 135 & $1.620,00$ & $1.782,00$ & $1.944,00$ \\
\hline Sistema NFC-e / estoque & Sim & 200 & $2.400,00$ & $2.640,00$ & $2.880,00$ \\
\hline Seguro roubo + incêndio & Sim & 200 & $2.400,00$ & $2.640,00$ & $2.880,00$ \\
\hline Cielo - Máquina de cartão & Sim & 135 & $1.620,00$ & $1.782,00$ & $1.944,00$ \\
\hline Manutenção ares condicionado & Sim & 50 & 600,00 & 660,00 & 720,00 \\
\hline Contador & Sim & 880 & $10.560,00$ & $11.616,00$ & $12.672,00$ \\
\hline Total & & & $19.200,00$ & $21.120,00$ & $23.040,00$ \\
\hline Outras despesas & Item mensal? & Valor mensal & Total ANO 1 & Total ANO 2 & Total ANO 3 \\
\hline Embalagens & & & $1.000,00$ & $1.000,00$ & $1.000,00$ \\
\hline Materiais de limpeza & & & 250,00 & 300,00 & 330,00 \\
\hline Total & & & $1.000,00$ & $1.000,00$ & $1.000,00$ \\
\hline Total das Despesas & & & $67.048,00$ & $73.552,80$ & $80.207,60$ \\
\hline
\end{tabular}


Impostos e contribuições

Base de cálculo para impostos

Percentual médio de impostos pagos sobre a venda de produtos

Percentual médio de impostos pagos sobre a venda de serviços

Percentual médio de impostos pagos sobre o lucro

Resultados

\begin{tabular}{|c|c|c|c|}
\hline \multicolumn{4}{|c|}{ Projeção de resultados } \\
\hline & Ano 1 & Ano 2 & Ano 3 \\
\hline Receita Bruta Total & $311.400,00$ & $505.890,00$ & $773.190,00$ \\
\hline Vestuário e acessórios & $163.800,00$ & $254.100,00$ & $381.150,00$ \\
\hline Calçados & $67.200,00$ & $116.160,00$ & $185.856,00$ \\
\hline Enxoval & $12.000,00$ & $21.120,00$ & $29.040,00$ \\
\hline Passeios & $10.800,00$ & $19.800,00$ & $34.848,00$ \\
\hline Utilidades & $15.000,00$ & $24.750,00$ & $39.930,00$ \\
\hline Brinquedos & $21.000,00$ & $36.300,00$ & $54.450,00$ \\
\hline Higiene pessoal e cosméticos & $21.600,00$ & $33.660,00$ & $47.916,00$ \\
\hline (-) Impostos e deduções sobre vendas & $15.228,00$ & $24.670,80$ & $37.853,64$ \\
\hline Receita Líquida & $296.172,00$ & $481.219,20$ & $735.336,36$ \\
\hline (-) Custos dos produtos e serviços & $210.116,00$ & $311.205,80$ & $448.700,60$ \\
\hline Margem de Contribuição & $86.056,00$ & $170.013,40$ & $286.635,76$ \\
\hline Margem (\%) & $28 \%$ & $34 \%$ & $37 \%$ \\
\hline Despesas & $70.948,00$ & $\mathbf{7 7 . 8 1 7 , 6 0}$ & $84.837,20$ \\
\hline Despesas administrativas e de escritório & $31.008,00$ & $34.108,80$ & $37.209,60$ \\
\hline Despesas de marketing e comercialização & $15.840,00$ & $17.324,00$ & $18.958,00$ \\
\hline Despesas com serviços de terceiros & $19.200,00$ & $21.120,00$ & $23.040,00$ \\
\hline Outras despesas & $1.000,00$ & $1.000,00$ & $1.000,00$ \\
\hline Despesas com Pessoal & $3.900,00$ & $4.264,80$ & $4.629,60$ \\
\hline Lucro Bruto & $15.108,00$ & $92.195,80$ & $201.798,56$ \\
\hline (-) Impostos s/ Lucro & 0,00 & 0,00 & 0,00 \\
\hline Lucro Líquido & $15.108,00$ & $92.195,80$ & $201.798,56$ \\
\hline
\end{tabular}


Fluxo de caixa

\begin{tabular}{|c|c|c|c|c|}
\hline \multicolumn{5}{|l|}{ Fluxo de caixa } \\
\hline Entradas & Período 0 & Total ANO 1 & Total ANO 2 & Total ANO 3 \\
\hline \multirow[t]{2}{*}{ Receitas } & & \multirow{2}{*}{$\begin{array}{c}311.400,00 \\
0,00\end{array}$} & \multirow{2}{*}{$\begin{array}{c}505.890,00 \\
0,00\end{array}$} & \multirow{2}{*}{$\begin{array}{c}773.190,00 \\
0,00\end{array}$} \\
\hline & & & & \\
\hline Total & 0,00 & $311.400,00$ & $505.890,00$ & $773.190,00$ \\
\hline Saidas & Período 0 & Total ANO 1 & Total ANO 2 & Total ANO 3 \\
\hline Deduções & & 0,00 & 0,00 & 0,00 \\
\hline Impostos sobre as vendas de produtos & & $15.228,00$ & $24.670,80$ & $37.853,64$ \\
\hline Custos totais & & $210.116,00$ & $311.205,80$ & $448.700,60$ \\
\hline Despesas totais & & $70.948,00$ & $77.817,60$ & $84.837,20$ \\
\hline Investimentos & $77.958,44$ & 0,00 & 0,00 & 0,00 \\
\hline Total & $77.958,44$ & $296.292,00$ & $413.694,20$ & $571.391,44$ \\
\hline Fluxo de caixa líquido & $-77.958,44$ & $15.108,00$ & $92.195,80$ & $201.798,56$ \\
\hline Fluxo de caixa acumulado & $-77.958,44$ & $-62.850,44$ & $29.345,36$ & $231.143,92$ \\
\hline
\end{tabular}

Análise de investimentos

\begin{tabular}{|l|r|r|}
\hline \multicolumn{3}{|c|}{ Fluxo de Caixa } \\
\hline Investimento & - R\$ & $77.958,44$ \\
\hline Ano 1 & R\$ & $15.108,00$ \\
\hline Ano 2 & R\$ & $92.195,80$ \\
\hline Ano 3 & R\$ & $\mathbf{2 0 1 . 7 9 8 , 5 6}$ \\
\hline & & \\
\hline TIR & & $\mathbf{7 3 , 5 1 \%}$ \\
\hline VPL 15\%a.a. & R\$ & $\mathbf{1 3 7 . 5 7 8 , 0 5}$ \\
\hline
\end{tabular}

Payback = De acordo com a análise da planilha de fluxo de caixa, o período de payback ocorre no segundo ano de existência da empresa, mais precisamente no vigésimo primeiro mês.

Ponto de equilíbrio (ano 1)

Despesas fixas totais: $\mathrm{R} \$ 70.948,00$ Margem de contribuição: $28 \%$ Ponto de equilíbrio: $\mathrm{R} \$ 70.948,00$ / $28 \%$ $=\mathrm{R} \$ 253.385,71$ 


\section{Ponto de equilíbrio (ano 2)}

Despesas fixas totais: $\mathrm{R} \$ 77.817,60$ Margem de contribuição: $34 \%$ Ponto de equilíbrio: $\mathrm{R} \$ 77.817,60$ / 34\%

$=\mathrm{R} \$ 228.875,29$

\section{Ponto de equilíbrio (ano 3)}

Despesas fixas totais: $\mathrm{R} \$$ 84.837,20 Margem de contribuição: 37\% Ponto de equilíbrio: $\mathrm{R} \$$ 84.837,20 / 37\% $=\mathrm{R} \$ 229.289,73$ 